\title{
Medicinal and theraptic properties of minor fruits - A Review
}

\section{Prakash Chandra Tripathi}

\author{
Division of Fruit Crops \\ ICAR-Indian Institute of Horticultural Research \\ Hessaraghatta Lake Post, Bangalore- 560089 \\ Email: prakaashtripathii2000@yahoo.co.in \\ Received : 20.05.2021; Revised : 20-07-2021 ; Accepted : 25.07.2021
}

\begin{abstract}
A large number of minor and wild fruit species have originated in Indian subcontinent. Many of these fruits or their plants parts have been used in folk, Ayurvedic and Unani medicines since time immemorial. Several fruits were introduced in India during colonial period. Most of them adapted to climatic conditions of India but remains minor crops. These fruits also have several medicinal properties and were used by the native people of their respective origin of centres. Some the fruits such as bael, aonla, jamun, tamarind, karonda, wood apple, kokum etc were known for their use in Indian pharmacopeia. The exotic fruits such as sour sop, rambutan, mangosteen, avocado, water apple, durian, passion fruit, carambola etc. have been reported for their different medicinal importance. These fruits contain several chemical ingredients such flavonoids, quinolizidine, alkaloids, tritepenes, stilbenes, tannins, steroids, coumarin, saponins, triterpenoids, glycosides, taraxerone, cryptoxanthin, taraxerol, etc. These exhibited varied biological effects like anti-inflammatory, analgesic, ant diabetic, antipyretic, antioxidant, hypoglycaemic, hepatoprotective, anticancerous. In recent years the global focus is shifting towards the plant based medicines and there is lot of research is being done on these fruits. Thus an attempt has been made in this article to compile the information available in the minor fruits.
\end{abstract}

Keywords: Antioxidants, medicinal value, minor fruits, theraptic properties

There are more than three thousand of edible fruits species in the world. These were used by human being some times in therein diet. The commercialization of agriculture led emphasis on few edible fruit species. As results of this, more than 75 percent of the global area and production of fruits is comprised by few species such as Banana and plantain, apple, citrus fruits, grapes, etc. (Anomymous, 2019). There are quite a large number of underutilized and wild fruit species, which are being used by the local inhabitants, to meet their dietary requirements (Ashrafuzzaman et al., 2021). In fact the underutilized fruits are not only source of food, vitamin and mineral requirements but also the source of livelihood because of their food and curative properties (Das, 2021). Many of these fruits or their plants parts have been used in local medicine. In India many of them are used in Ayurvedic and Unani medicines since time immemorial. Apart from their nutritive and medicinal values quite a few of these underutilized fruits have excellent flavour and very attractive colour. In spite of these quality attributes most have not undergone any conscious phase of domestication and human selection. Their cultivation is very restricted and they grow mainly wild. As far as the native fruits are concerned, several fruit plant species have originated in Indian subcontinent. India is centre of origin of jack fruit, bael, aonla, ber, khejri, jamun, tamarind, mahua, phalsa, Lasoda, karonda, wood apple, pilu, bilimbi, Garcinia, and several other wild fruits (Table 1). Several minor fruits such as Rambutan, mangosteen, longan, avocado, water apple, hog plum, macadamia nut, kiwifruit, longsat, durian, passion fruit, dragon fruit, pulasan, carmbola, etc. were introduced during last few centuries and several are naturalized in Indian conditions (Table 2). Apart from these there more than 100 wild edible fruits native to India which are yet to be domesticated but these are gathered from forest by the rural and tribal people and sold in the rural market (Tripathi et al., 2018).

There is lot of sctter information avaible on the medicinal and therapeutic prpeoerties of minor fruits. Thus an attempt has been made in this artilce to compile these informations in a precise way. 

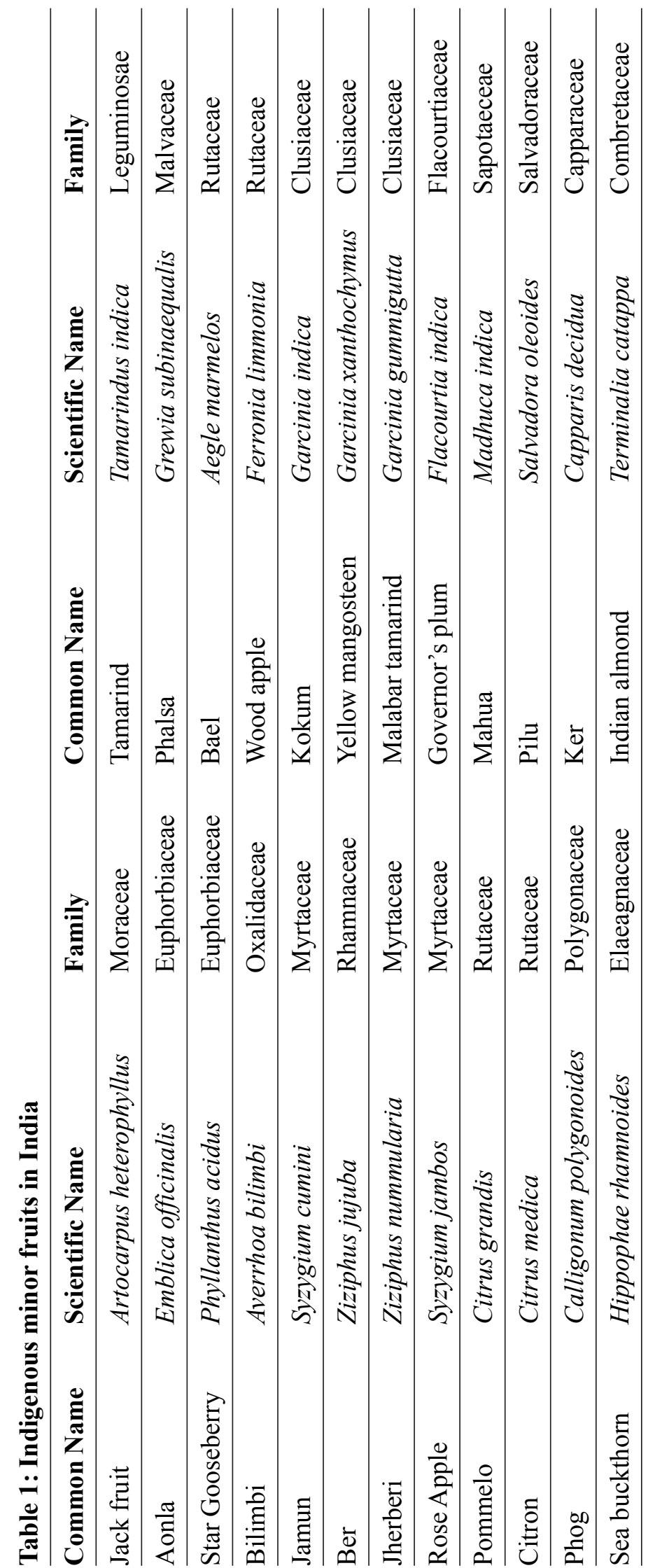

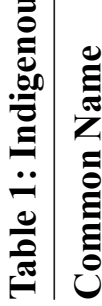

IJMFM\&AP, Vol. 7 No. 2, 2021

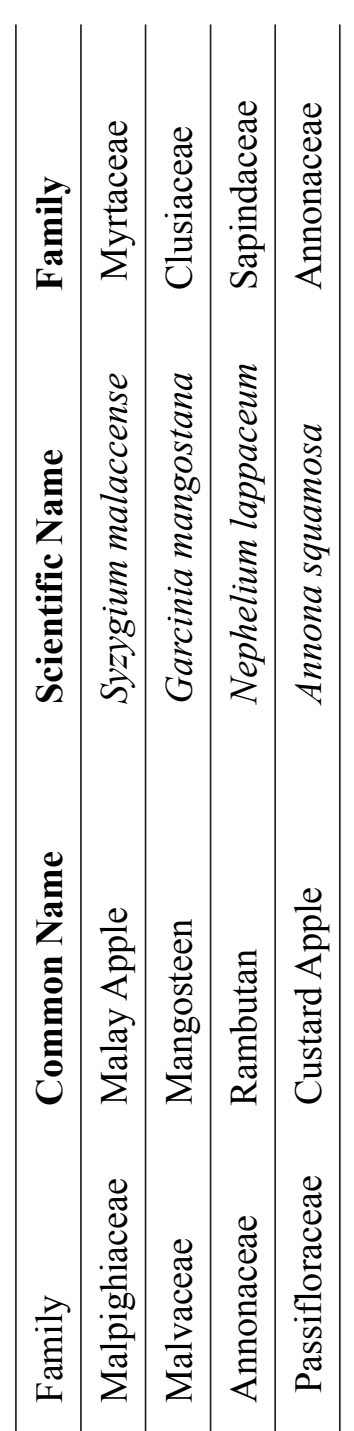

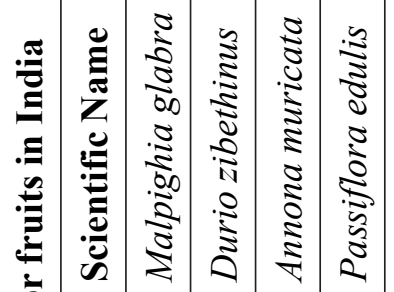

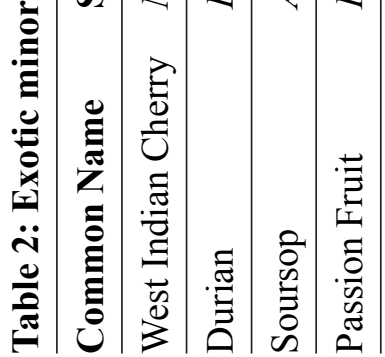




\subsection{Phytochemicals in minor fruits}

Fruits are rich source of vitamins and minerals. Besides, nutritional importance, these fruits have medicinal and theraptic values. Fruits contain several chemical ingredients such as flavonoids, quinolizidine, alkaloids, tritepenes, stilbenes, tannins, steroids, coumarin, and saponins, quinolizidine, triterpenoids, glycosides, fatty acids, taraxerone, cryptoxanthin, taraxerol, $\beta$-carotene, (24R)-24-ethylcholest-5-en-3 $\beta$-ol glucoside, and $\beta$ sitosterol, etc. These exhibited varied biological effects like anti-inflammatory, analgesic, antidiabetic, antipyretic, antioxidant, hypoglycemic, hepatoprotective, and anticancer, dysentery, cholera, wounds, and sores (Doka et al., 2014; Ebbo et al., 2014; Ibragic and Sofic, 2015; Goyal, 2012). Flavonoids are a large group of natural substances with variable structures present almost in all growing parts of the plants, being reported as the most abundant plant pigment along with chlorophyll and carotenoids, also providing fragrance and taste to fruits, flowers and seeds, which makes them attractants for other organisms. These compounds are also one of the largest groups of secondary metabolites. Besides their relevance in plants, flavonoids are important for human health because of their high pharmacological activities. Recent interest in these substances has been stimulated by the potential health benefits arising from the antioxidant activities of these polyphenolic compounds. Minor fruits are rich source of antioxidants. The antioxidants play an important role in health-promoting biochemical pathways. Oxidative stress, resulting from imbalance among the reactive oxygen species including free radicals and antioxidant defences in living organisms produces oxidative changes to proteins, fatty acids, and DNA molecules in the living cells, which encourage the initiation of ailments, e.g., inflammation, liver cirrhosis and vascular diseases (Aruoma, 1998). Phenolic compounds are the largest group of phytochemicals found in the plants. Phenols, as the major bioactive substances in fruits, play a vital role as antioxidant. Phenolic compounds are good antioxidants found in the flesh of fruits including phenolic acids and flavonoids, whereas flavonoids and lignans are found in the seeds or kernel. Among the phenolic acids, gallic acid is the major component of plant. Each fruit has, at least, a few major phenolic compounds. In addition to fruit, catechin is one of the main flavonoids found in leaves. Since phenolics are potent antioxidants, increased consumption of a mixture of fruits daily should be able to provide an adequate phenolic antioxidant. Among hundreds of types of flavonoids, quercetin is a bioactive flavonoid isolated from the fruit. Besides quercetin, geraniin, quercetin 3- $\beta$-D-glucopyranoside, kaempferol 3- $\beta$ D-glucopyranoside, isocorilagin, and kaempferol were detected. To date, only a very limited information on phenolic compounds is available for the scientific community, especially phenolic compounds in the minor fruits such as Baccaurea, Cynometra, Garcinia, durian etc. Monoterpenes, diterpenes, triterpenes, and sesquiterpenes are some of the terpenes. Terpenoid is a vast and diverse class of natural occurring organic chemicals related to terpene. Most of the terpenoids including saponins are possible antioxidants. Besides antioxidant activity, saponins have several health benefits. Among the terpenes and terpenoids, some are volatile compounds found in plants. Geraniol, limonene, linalool, and pinene are some of the volatile components detected in fruit samples. Terpenes, mainly sesquiterpenes, have been identified in the root, bark, flowers, and leaves of plants. Only a few terpenes have been discovered in fruits. Although many studies have been performed on volatile terpenes in essential oils of plants, most of the studies analyzed the other parts of the plant rather than the fruit. From our literature search, a minimum of 20 volatile components including terpenes were found in different parts of the plant. Little information on terpenes and terpenoids content in fruit is available for the scientific community, especially the underutilized and indigenous tropical fruits. The carotenoids are classified as terpenoids. The compounds are found abundantly in yellow to orange- and orange to red-colored fruits. Carotenoids are grouped into carotenes and xanthophylls. In nature, $\beta$-carotene is the most abundant type of carotene, while lycopene is the primary phytochemical in orange-red colored fruits. Among the xanthophylls, lutein is typically detected in green leafy vegetables. However, some fruits also contain lutein. Among the carotenes, all- 
trans $\hat{a}$-carotene is the most common type of carotenoid found in plant because it is part of the antioxidant defence system at cellular level of a plant. Some green-colored fruits may contain a high amount of carotenoid because the yellow-orangecoloured carotenoid pigments are masked by chlorophylls. The intake of carotenoids from various plant sources is thought to be able to maintain good health. There are several phytochemicals present in minor fruits. Some are unique for particular species and some are present in most of the fruits but their quantity may vary in different plants as well as in their plant parts. Some of the phytochemical presnt in some minor fruits are given in Table 3.

Table 3: Phytoconstituents in various parts of minor fruits

\begin{tabular}{|c|c|c|}
\hline Fruit species & Plant Part & Phytoconstituents \\
\hline \multirow[t]{5}{*}{$\begin{array}{l}\text { Aonla (Emblica } \\
\text { officinalis) }\end{array}$} & Leaf & $\begin{array}{l}\text { Gallic acid, chebulic acid, ellagic acid, chebulinic acid, chebulagic acid, amlic } \\
\text { acid, alkaloids phyllantine and phyllantidine (Khan, 2009). }\end{array}$ \\
\hline & Fruit & $\begin{array}{l}\text { Gallic acid } 1.32 \% \text {, tannin, gum } 13.75 \% \text {; albumin } 13.08 \% \text {; crude cellulose } 17.08 \% \text {; } \\
\text { mineral matter } 4.12 \% \text { and moisture } 3.83 \% \text {. Amla fruit ash contains chromium, } \\
2.5 \text { ppm; zinc } 4 \text { ppm; and copper, } 3 \text { ppm (Kumar et al., 2012a). }\end{array}$ \\
\hline & Stem Bark & Leukodelphinidin, tannin and proanthocy-anidin (Khan, 2009) \\
\hline & Seed & $\begin{array}{l}\text { linolenic acid }(8.78 \%) \text {, linoleic }(44 \%) \text {. oleic }(28.40 \%) \text {, steric }(2.15 \%) \text {, palmitic } \\
(2.99 \%) \text { and miristic acid }(0.95 \%)(\mathrm{Khan}, 2009) .\end{array}$ \\
\hline & Root & Ellagic acid and lupeol (Khan, 2009). \\
\hline \multirow[t]{5}{*}{$\begin{array}{l}\text { Bael (Aegle } \\
\text { marmelos) }\end{array}$} & Leaf & $\begin{array}{l}\text { Tannins, Limonene, Aegelin, p- Cymene Phellandrene, Cineole, Skimmianine } \\
\text { (Maity et al., 2009); O-(3, 3-dimethylallyl)- halfordinol (Manandhar et al., 1978); } \\
\text { Marmelosin (Nandkarni, } 1976 \text { ); Marmesinin, Rutin, } \beta \text { - Sitosterol-D- glucoside, } \\
\text { Marmeline(Sharma et al., 1980); Umbelliferone (Arul et al., 2004); Y-Sitsterol, } \\
\text { flavones, lupeol, eugenol, citral, Glycoside, O-isopentenyl, Citronellal, } \\
\text { Cuminaldehyde phenylethyl cinnamamides (Farooq, 2005) }\end{array}$ \\
\hline & Fruit & $\begin{array}{l}\text { Alloimperatorin, Imperatorin Scoparone, Scopoletin (Sharma et al., 1980); } \\
\text { Auraptene (Kakiuchi et al., 1991); Calcium compounds, Linoleic acid (Maity et } \\
\text { al., 2009); Glutamic acid, Glycine, Lysine, Magnesium compounds, } \\
\text { Phenylalanine, Proline, Skimmin, Umbelliferone, Xanthotoxol (Barthakur and } \\
\text { Arnold, 1989); Marmelosine (Badam et al., 2002); Psoralen (Chakthong et al., } \\
\text { 2012); Luvangetin, Marmelide, Tannin (Farooq, 2005) }\end{array}$ \\
\hline & Stem Bark & Fagarine, Marmin (Chatterjee and Mitra, 1949) ;Skimmianine (Maity et al., 2009) \\
\hline & Seed & $\begin{array}{l}\text { Anthraquinones (Mishra et al., 2009); Linoleic acid, Linolenic acid, Palmitic } \\
\text { acid, Stearic acid (Singh and Malik, 2000); Essential oil: D-limonene, A-D- } \\
\text { phellandrene, Cineol, Citronellal, Citral, P-cyrnene, Cumin aldehyde (Farooq, } \\
\text { 2005) }\end{array}$ \\
\hline & Root & $\begin{array}{l}\text { Á- Methyl scopoletin, Skimmin, Scopoletin, Timbamine (Shoeb et al., 1973); } \\
\text { Psoralen, Umbelliferone, Xanthotoxin (Basu and Sen, 1974) }\end{array}$ \\
\hline \multirow[t]{2}{*}{$\begin{array}{l}\text { Wood apple } \\
\text { (Ferronia } \\
\text { limmonia) }\end{array}$} & Fruit & $\begin{array}{l}\text { Flavonoids, glycosides, saponins and tannins , tyramine derivatives (Ilango and } \\
\text { Chitra, 2010), Flavone glycoside - 5,4-dihydroxy-3-(3-methyl-but-2-enyl) 3,5,6- } \\
\text { trimethoxyflavone7-O-b-D-glucopyranoside (Amin et al,2017 ), Citric acid, , } \\
\text { alkaloids, coumarins, fatty acids, sterols, umbelliferone, dictamnine, xanthotoxol, } \\
\text { scoparone, xanthotoxin, isopimpinellin, isoimperatorin and marmin (Pratima } \\
\text { Vijavyargia et al, 2014) }\end{array}$ \\
\hline & Leaf & $\begin{array}{l}\text { Alkaloids - Psoralen, bergapten. Flavones - Orientin, vitexin Saponins Essential } \\
\text { oils (Amin et al, 2017). Eudesma-4 (Thomas and Ponnammal, 2005), 11-dine } \\
(46.3 \%) \text {, carvacrol (29.6\%) and 1,5-cyclodecandine }(13.4 \%), \alpha \text {-Thujene, } \\
\alpha \text { Pinene, Linalool 0.1, 1,5-Cyclodecandine, Caryophyllene 1.3, cis-Anethole, } \\
\text { Elemicin 0.9, Aromadendrene, Germacrene-D, 3,4-Dimethyl cinnamic alcohol, } \\
\text { Veratraldehyde, Caryophyllene oxide (Senthil Kumar et al, 2010), Stigmasterol, }\end{array}$ \\
\hline
\end{tabular}

Contd. 


\begin{tabular}{|c|c|c|}
\hline Fruit species & Plant Part & \multirow{2}{*}{$\begin{array}{l}\text { Phytoconstituents } \\
\text { orientin, vitedin, saponarin, tannins (Pratima Vijavyargia et al, 2014), } \\
\text { Carbohydrate, amino acid, protein, lipid, tannins, alkaloids, steroids (Patil et al, } \\
2012 \text { ) }\end{array}$} \\
\hline & & \\
\hline & Seed & Fixed oil, carbohydrates, proteins and amino acids \\
\hline & Shell & Psoralene, xanthotoxin, 2, 6-dimethoxybenzoquinone, osthenol (anti-fungal) \\
\hline & & $\begin{array}{l}\text { (llango and Chitra, 2010), Amino acid, total amino acid (Thomas and } \\
\text { Ponnammal,2005) }\end{array}$ \\
\hline & Bark & $\begin{array}{l}\text { Coumarins - Marmesin, bergapten, psoralen, luvangetin, xanthotoxin, scopoletin, } \\
\text { isoimperatorin, osthol and 6,7-dimethoxycoumarin " feronolide and feronone } \\
\text { (Pratima Vijavyargia et al, 2014), Alkaloids Steroids - Sitosterol and sitosterol- } \\
\text { o-beta-d-glucoside. Terpenoids - Lupeol and limonin Flavones - 5, 7-dihydroxy- } \\
\text { 3', 4'-dimethoxy-6,8-di (3-methylbut-2-enyl) stigmasterol, sitosterol-3-O- } \beta \text {-D- } \\
\text { glucopyranoside. The bark of the plant has yielded (-)(2S)-5,3'-dihydroxy-4'- } \\
\text { methoxy-6",6"dimethyl chromeno-(7,8,2",3")-flavanone along with several } \\
\text { known compounds, five coumarins, a flavanone, a lignan, (antimicrobial) (Ilango } \\
\text { and Chitra, 2010), Carbohydrate, amino acid, protein, lipid tannins (Patil et al, } \\
\text { 2012), Phenols (Thomas and Ponnammal,2005) }\end{array}$ \\
\hline & Root & $\begin{array}{l}\text { Lactones - Feronia lactone, geranylumbelliferone, frenolin. Coumarin - Aurapten, } \\
\text { marmesin, bergapten, xanthotoxin, osthol, xanthyletin, 6-methoxy-7- } \\
\text { geranyloxycoumarin, osthenol. Quinolone alkaloid - 1-methyl-4-methoxy-2- } \\
\text { quinolone (Amin et al, 2017) }\end{array}$ \\
\hline $\begin{array}{l}\text { Bilimbi (Averrhoa } \\
\text { bilimbi) }\end{array}$ & Fruit & Flavonoids, saponins, and triterpenoids (Hock Eng Khoo et al, 2016) \\
\hline $\begin{array}{l}\text { Rose apple } \\
\text { (Syzygium jambos) }\end{array}$ & Fruit & Phenols, tannins, alkaloids, and flavonoids (Hock Eng Khoo et al, 2016) \\
\hline $\begin{array}{l}\text { Malayan apple } \\
\text { (Syzygium } \\
\text { malaccense) }\end{array}$ & Fruit & Phenolic compounds and terpenes (Hock Eng Khoo et al, 2016) \\
\hline $\begin{array}{l}\text { Jherberi (Ziziphus } \\
\text { mauritiana) }\end{array}$ & Fruit & Phenolic compounds and saponin (Hock Eng Khoo et al, 2016) \\
\hline \multirow[t]{3}{*}{$\begin{array}{l}\text { Karonda } \\
\text { (Carissa carandus) }\end{array}$} & Fruit & $\begin{array}{l}\text { L Ascorbic acid, Chlorogenic acid, Ellagic acid, Piceatannol, Resveratrol. Syringic } \\
\text { acid, Vanillic acid, p Coumaric acid, Caffeic acid, Epicatechin, Rutin, Carissol } \\
\text { (Kaunda and Zhang, 2017, Patil et al., 2012; Pandya, 2012; Parvin,2018) }\end{array}$ \\
\hline & Leaf & $\begin{array}{l}\text { Carissic acid, Carissic acid methyl ester, Carissic acid monoacetate, Betulinic } \\
\text { acid, Carandinol(Kaunda and Zhang 2017, Patil et al., 2012; Pandya, 2012; } \\
\text { Parvin,2018) }\end{array}$ \\
\hline & Flower & $\begin{array}{l}\text { Nerolidol, Farnesol, Camphene, Menthol, p Cymene, } \alpha \text { Terpineol, Neryl acetate, } \\
\text { Neryl acetate, Geranyl acetate(Kaunda and Zhang 2017, Patil et al., 2012; Pandya, } \\
\text { 2012; Parvin,2018) }\end{array}$ \\
\hline
\end{tabular}

\subsection{Minor fruits in folk medicine}

A number of species of minor fruits are being used by the people in as suitable food, food supplements and sources of spices and condiments, edible oils, medicine, etc. A number of studies have shown the use of locally available indigenous or traditional fruit speices and their plant parts in medicine by indigenous communities. Some of them are tabulated as Table 4.

\section{Medicinal and pharmceatical properties 3.1 Therapeutic values}

The therapeutic value of some minor fruits such as aonla (Indian goose berry), Jamun, kokum etc is known since time immortal. Aonla fruit is traditionally known for its medicinal value in India for the treatment of several health complications, suchas diarrhea, dysentery, anemia, jaundice, and 
Table 4: Use of minor fruits in folk medicine

\begin{tabular}{l|l}
\hline Fruits & Use in folk medicine \\
\hline Bael & $\begin{array}{l}\text { Abdominal pain, cholera, night fever, stomach disorder and snake bite. They use } \\
\text { specially fruits and roots for treating gastric troubles. Roots of Bael for curing bite of mad } \\
\text { dog. leaves use for treatment of heat in abdomen and jaundice, diabetes, fruit is used as a } \\
\text { laxative by different tribes of India (Gupta, 2016), root bark as fish Poison and use the leaf } \\
\text { paste as an antivenom against venom of poisonous insects and animals. The powder of } \\
\text { fruit and bark is used for the treatment of stomachache and dysentery in eastern Rajasthan } \\
\text { (Joshi, 1986) }\end{array}$ \\
\hline $\begin{array}{l}\text { Bilimbi } \\
\text { (Averrhoa bilimbi) }\end{array}$ & $\begin{array}{l}\text { Ripe fruits combined with pepper for inducing sweating; pickled bilimbi is smeared all } \\
\text { over the body to hasten recovery after a fever; fruit conserves for treatment of coughs, } \\
\text { beriberi, and biliousness; fruit syrup for reducing fever and inflammation and to alleviate } \\
\text { internal haemorrhoids (Lim, 2012) }\end{array}$ \\
\hline $\begin{array}{l}\text { Aonla } \\
\text { (Emblica Officinlis) }\end{array}$ & $\begin{array}{l}\text { Fruit for treating cough and asthma, and several other health complications in Malaysia } \\
\text { (Mohamad et al., 2011) }\end{array}$ \\
\hline $\begin{array}{l}\text { Rose apple } \\
\text { (Syzygium jambos) }\end{array}$ & $\begin{array}{l}\text { Ripe fruit is used as a tonic for brain and liver and as a diuretic; seeds for treatment of } \\
\text { diarrhea, dysentery, and catarrh (Morton, 1987) }\end{array}$ \\
\hline $\begin{array}{l}\text { Malayan apple } \\
\text { (Syzygium } \\
\text { malaccense) }\end{array}$ & Fruit decoction as a febrifuge (Morton, 1987) \\
\hline $\begin{array}{l}\text { Jherberi } \\
\text { (Ziziphus mauritiana) }\end{array}$ & $\begin{array}{l}\text { Ripen fruit for treatment of sore throat and cough; seed for treatment of diarrhea and } \\
\text { weakness of stomach [(Morton,1987), Marwat } e t \text { al., 2009] }\end{array}$ \\
\hline Karonda & Roots are used
\end{tabular}

\begin{tabular}{l|l} 
Karonda & Roots are used as stomachic, anthelmintic and antiscorbutic; in curing stomach disorders
\end{tabular} (Carissa carandus) including flatulence and acidity, intestinal worm infestation, diabetic ulcer, scabies, pruritus, pyrexia, urinary disorders, chronic ulcer and biliousness; and even acts as insect repellent (Kumar et al, 2013, Trivedi, 2004). Used in the treatment of remittent fever, diarrhoea, earache, mouth and throat soreness, and syphilitic pains, (Kumar et al., 2013 Trivedi, 2004). Unripe fruit used as an appetiser, astringent, antiscorbutic, acidic, stomachic, anthelmintic, laxative and antipyretic, and in curing anorexia, diarrhoea and haematemesis (Kumar et al., 2013; Trivedi, 2004). Ripe fruits are used as an appetiser, antiscorbutic and expectorant; in curing anorexia, burning sensation, pruritus and skin disorder; in the treatment of anaemia; as antidote for poisons and carminative; for female libido improvement; in curing worm infestation; as antimicrobial and antifungal; in insanity treatment (Khare 2007; Bisset,1994, Sharma et al., 2007).

Jamun (Syzygium $\quad$ Infusion of fruit or mixture of powdered bark and fruit is used to treat diabetes in North cumini) east India(Sharma et al., 2001).The juice of ripe fruits is stored for 3 days and then is given orally for gastric problems. The juice obtained from the bark is given orally for the treatment of women with a history of repeated abortion in Lakher and Pawi in North east India. Fruit and stem bark are used in the treatment of diabetes, dysentery, increases appetite and headache in Maharashtra (Jain et al., 2005). Decoction of stem bark is taken orally three times a day for 2-3 weeks to treat diabetes (Chhetri et al., 2005). Leaves are used in the treatment of diabetes and renal problems by native indians and Quilombolas in North eastern Brazil (de Albuquerque et al., 2007). Leaves juice with honey or cow's milk used to treat diabetes. Fresh fruits are taken for stomachache and to treat diabetes by Kani tribals in Southern India (Ayyanar, 2008; Udayan et al., 2006). Seeds are taken orally for diabetes in Madagascar (Ratsimamanga, 1998). Dried seeds powder is taken orally thrice a day in the treatment of diabetes in Andhra Pradesh (Nagaraju et al. 2006). The juice obtained from the leaves is mixed with milk and taken orally early in the morning, to treat diabetes

Contd. 
by Siddis in Karnataka (Bhandary et al., 1995). The juice of stem bark is mixed with butter milk to treat constipation. Leaves are taken orally for treatment of diabetes in Brazil (Braga et al., 2007). The tender leaves are taken orally to treat jaundice in Maharashtra (Natarajan and Paulsen, 2000).

Rambutan (Nephelium lappaceum)

cos

\begin{tabular}{l|l} 
Kokum (Garcinia & T \\
indica) & de
\end{tabular}

Unripe fruit is astringent, stomachic; acts as a vermifuge, febrifuge, and is taken to

relieve diarrhea and dysentery. The leaves are poulticed on the temples to alleviate headache.

In Malaya, the dried fruit rind is sold in drugstores and employed in local medicine. The astringent bark decoction is a remedy for thrush. A decoction of the roots is taken as a febrifuge.

Traditionally, kokum is used in herbal medicines to treat diarrhoea, inflammatory ailments, dermatitis, bowel problems, rheumatic pains and to prevent hyper perspiration. Fruits are used as antihelmintic and cardiotonic. Kokum juice from the rind is used against piles, colic problems, dysentery and diarrhoea (Baliga et al., 2011). Decoction of fruit rinds are traditionally used against diabetes. Kokum butter is used traditionally to healwounds, fissures in hands and is supposed to restore elasticity of skin and used as a moisturiser (Jeyarani and Reddy, 1999; Padhye et al., 2009). Leaves of G. indica are used to treat skin ulcers, dyspepsia and hyperplasia.

Malabar Tamarind
(Garcinia gummigutta)

Treatment of edema, delayed menstruation, ulcers, open sores, hemorrhoids, fever,

a) rheumatism, and also against intestinal parasites (Majeed et al., 1994, Semwal et al., 2015).

The astringent properties of the rind make it an indispensible ingredient in gargles for weak gums, bowel complaints, constipation, diarrhoea and dysentery. The plant is used in veterinary medicine, for mouth diseases in livestock.

\begin{tabular}{l} 
Yellow mangosteen \\
(Garcinia \\
xanthochymus) \\
\hline Mangosteen (Garcinia \\
mangostana)
\end{tabular}

Plant is widely used as a traditional folk medicine for bilious condition, diarrhea, dysentery, anthelmintic, cardiotonic and as a tonic to improve appetite (Whitmore, 1973; Perry, 1980; Baishya et al., 2013; Joseph et al, 2016). In traditional Chinese Dai medicine, it is used for expelling worms and removing food toxins (Lin et al., 2003)

Peel and seed in the form of infusions and decoctions used to treat infections of skin, urinary tract, and gastrointestinal, and act as laxative, anti-scorbutic, and anti-fever agent (Ovalle-Magallanes et al., 2017). Treatment of diarrhea, abdominal pain, dysentery, suppuration, wound infection, and chronic ulcer (Cui et al., 2010; Gorinstein et al., 2011; Suksamram et al., 2006) and to treat inflammatory and immunological related-diseases, such as acne, food allergies, and arthritis (Wang et al., 2017).

\begin{tabular}{l|l}
\hline Passion fruit & $\begin{array}{l}\text { Passiflora (or Passion flower) is a folk remedy used for anxiety (Miyasaka et al., 2007; } \\
\text { (Passiflora edulis) }\end{array}$ \\
$\begin{array}{l}\text { Reginatto et al., 2006). Several species of Passiflora have been employed widely as a folk } \\
\text { medicine because of sedative and tranquillizer activities (Barbosa } \text { et al., 2008). Passiflora, } \\
\text { an herbal medicine, could be an op-tion for treating anxiety if shown to be effective and } \\
\text { safe (Miyasaka } \text { et al., 2007). }\end{array}$
\end{tabular}

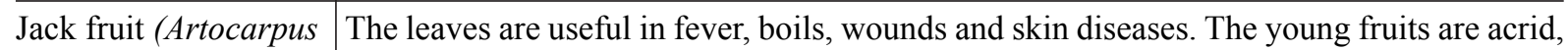
$\begin{array}{lll}\text { heterophyllus) } & \text { astringent, and carminative. The ripe fruits are sweet, cooling, laxative, aphrodisiac and }\end{array}$ also used as a brain tonic. The seeds are, diuretic, and constipating. The wood is nervine, antidiabetic, sedative and is useful in convulsions (Hemborn, 1996). The latex is useful in dysopia, ophthalmic disorders and pharyngitis and also used as antibacterial agent (Sato et $a l .$, 1996). The ash of Jackfruit leaves is used in case of ulcers. The dried latex yields artostenone, convertible to artosterone, and a compound with marked androgenic action. Mixed with vinegar, the latex pomotes healing of abscesses, snakebite and glandular swellings (Vaidya Gogte, 2000). The root is a remedy for skin diseases and asthma. An extract of the root is taken in cases of fever and diarrhoea. The bark is made into poultices. Heated leaves are placed on wounds. The wood has a sedative property and its pith is said to be abortifacient. Latex is used as an anti-inflammatory agent (Gupta and Tandon, 2004). 
cough (Chopra et al., 1992). The fruit is also rich in antioxidant. A study on the healing activity of ethanolic extract of aonla fruit has shown some positive results, where the rats were induced with indomethacin $(30 \mathrm{mg} / \mathrm{kg} \mathrm{BW}$, oral intubation) (Bhattacharya et al., 2007). The results showed that the extract $(100 \mathrm{mg} / \mathrm{kg} \mathrm{BW})$ of this fruit had significantly reduced the lipid peroxidation parameters (MDA, carbonyl, total DNA, SOD, and CAT), ulcer index (3.8), and DNA damage induced by indomethacin $(85.73 \%$ of protection) in rats after seven days of postulcerative treatment compared with the controls. Other than that, the extract of emblic fruit also inhibited the growth of Staphylococcus aureus, Bacillus subtilis, Salmonella paratyphi, Shigella dysenteriae, and Candida albicans (Ahmad and Beg, 2001). The aqueous extract of aonla has shown the potential as an anticancer agent, where the extract inhibited the growth of human lung carcinoma and (A549) and human hepatocellular carcinoma (HepG2) celllines (Bhattacharya et al., 2007). Moreover, the emblic fruit powder demonstrated a significant chondroprotective effect based on an in vitro model of cartilage degradation in explant cultures of articular knee cartilages obtained from osteoarthritis patients (Sumantran et al., 2008). The fruit extract of jamun is reported on the medical properties. The methanolic extracts of jamun leaves were tested for antimicrobial activity, where the extracts inhibited the growth of some Gram-positive and Gramnegative bacteria (Mohanty and Cock, 2010). Besides that, antimicrobial activities of the extracts of bark, leaves, and seeds of rose apple have also been reported by Murugan et al. (2011). The leaves of $S$. malaccense (Malay apple) were reported to be useful for preventing inflammation (Cox,1993). Most of the plants from genus Garcinia have medicinal effects. In Southeast Asia, only a few studies were reported on the potential medicinal properties of underutilized Garcinia fruits. The fruit extract of $G$. hombroniana inhibited in vitro lipid peroxidation and had antiplateletactivities (Jantan et al., 2011). Kapadia and Rao (2011) report antimicrobial effects of Garcinia plants towards bacteria, fungus, and other parasites. The stems and leaves of three Garcinia plants indicate plateletactivating factor antagonist activity (Hemshekhar et al., 2011). The main bioactive compound in the leaves that possess antimicrobial effect is reported as garcihombronane (Kapadia and Rao, 2011). Most of the plants from genus Garcinia have antihypercholesterolemic effect (Hemshekhar et al., 2005). The fruit extract of $G$. hombroniana inhibited in vitro lipid peroxidation and had antiplateletactivities (Jantan et al., 2011). Indian jujube is known for its medicinal properties. It is traditionally used for treating abscesses, wounds, anodyne, and tonic, as well as styptic and purifying blood. The leaves of Z. Mauritiana were reported to significantly prevent leucopenia and noise induced enhancement of neutrophil function in Guineapigs compared with diazepam, in which the Guinea pigs were subjected to $100 \mathrm{Db}$ industrial noise $(8-50 \mathrm{kHz})$ (Vakharia et al., 2014). Antioxidant activities have also been determined for the fruits from two varieties of Z. mauritiana, and the I50values of the ethanolic extract of both varieties (Beri and Narikeli) were 72 and $250 \mathrm{ug} /$ $\mathrm{mL}$, respectively (Nimbalkar and Rajurkar, 2009). The ethanolic extracts of $Z$. mauritiana seed were found to induce cancer cells death and significantly reduced tumor volume and tumor cell countin albino mice after 13 days of treatment with the extract (100-800mg/kg BW) (Mishra et al., 2011). Besides that, the seed extract exhibited hypoglycemic activity, where administration of the extract (at a concentration of $800 \mathrm{mg} / \mathrm{kg} \mathrm{BW}$ ) reduced weight loss and mortality of alloxaninduced diabetic mice (Bhatia and Mishra, 2010). The fruit of bilimbi (tree) has potential health benefits. According to Ambili et al (2009), the extracts of bilimbi exhibited the cholesterollowering potential in rats. The water extract of bilimbi fruit $(0.8 \mathrm{mg} / \mathrm{kg}$ body weight) improved lipid profile in Triton-induced hypercholesterolemia in rats. The active fraction of the water extract at a dose of $0.3 \mathrm{mg} / \mathrm{kg} \mathrm{BW}$ possessed an optimum antihypercholesterolemic activity. The fruit $(125 \mathrm{mg} / \mathrm{kg} \mathrm{BW})$ and its water extract $(50 \mathrm{mg} / \mathrm{kg} \mathrm{BW})$ also effectively improved the lipid profile of the rats fed with high-fat diet (Ambili et al., 2009). Besides that, this fruit is also reported as an active antimicrobial agent. Chloroform and methanolic extracts of bilimbi were reported to have good inhibitory activities on several types of bacteria, such as Aeromonas hydrophila, Escherichia coli, Klebsiella 
pneumoniae, Saccharomyces cerevisiae, Staphylococcus aureus, Streptococcus agalactiae and Bacillus subtilis (Wahab et al., 2009). Flavonoids and anthocyanins in dabai fruit $(C$. odontophyllum) are the potent antioxidants. The defatted dabaiextract $(5 \%)$ was shown to significantly reduce the levels of total cholesterol and low-density lipoprotein-cholesterolin rabbits supplemented with high-cholesterol diet for eight weeks as compared to the control group (Nurulhuda et al., 2013). Besides that, rabbits fed a highcholesterol diet and defatted dabaipulphave a significant increment in high-density lipoproteinlevel (Nurulhuda et al., 2012). The severity of atherosclerotic plaques in the highcholesterol diet rabbit group that supplemented with defatted dabai extracts was also reduced compared to the control group. Durian possesses some antiinflammatory properties. The methanolic extracts of $D$. zibethinus fruit were reported to have antiinflammatory effects (Leverett et al., 2005). The fruit of Cynometra cauliflora possesses antiproliferative activity by inhibition of cytotoxic effect to human promyelocytic leukemia HL-60 cells (Tajudin et al , 2012).The fruit of Syzygium jambos (rose apple) has been traditionally used as an astringent and for brain and liver, as well as digestive problems (Reynertson, 2007). The aqueous fruit extracts of rose apple reduced the in vitro glucosidase and amylase inhibitory activities (Das et al., 2012). The fruit extracts of Syzygium samarangense (samarang apple) were also as effective as antibiotics to inhibit microbial activities (Ratnam and Raju, 2008). Aqueous leaf extact of pasion fruit was more effective in suppressing the TNF $\alpha$ and IL- $1 \beta$ levels than dexamethasone. This may be a source of new therapeutic candidates with a spectrum of activity simi-lar to the current antiinflammatory steroids such as dexamethasone (Montanher et al., 2007).

\subsection{Antidiabetic activity}

Diabetes has become a common disease around the world. When the body cannot produce sufficient amount of insulin the blood glucose level increases. Antidiabetic aims at reducing the blood glucose level by inducing the production of a higher amount of insulin. Several plant and their parts have anti diabetic properties. Antidiabetic effect of Jamun is well known in Ayurveda. The seed powder of Jamun is effective in controlling high blood sugar levels. The hypoglycaemic effect of different parts of Jamun to control diabetes in preclinical models has been reported. Majority of the preclinical reports have indicated that different parts of Jamun reduced blood sugar levels in rodent models of diabetes and clinical setting. The seed powder extracted in water has shown to reduce blood sugar level in diabetic rabbits (Brahmachari and Augusti, 1961). The use of aqueous seed extract of Jamun at a dose of $1 \mathrm{~g} / \mathrm{kg}$ body weight in diabetic rats has been reported to produce hypoglycaemic effect in the blood (Kedar and Chakrabarti, 1983). Numerous studies on aqueous seed extract have been found to reduce blood sugar in the diabetic rats (Achrekar et al., 1991; Prince et al., 1998). The lyophilized powder of aqueous seed extract has been reported to decrease the blood glucose level in diabetic mice and rats (Vikrant et al., 2001; Grover et al., 2001).Similarly, aqueous jamun seed extract consisting of gummy fibres has been highly effective in controlling diabetes in alloxan induced diabetes in rats. The alloxan-induced diabetic rats and rabbits administered with ethanol extract of jamun seeds showed a decline in fasting blood glucose levels in an earlier study (Sharma et al., 2003). The jamun seed kernel extracted in ethanol reduced the blood glucose level in the streptozotocin-induced diabetic rats and also restored the activities of catalase, glutathione peroxidase and superoxide dismutase enzymes accompanied by restoration of glutathione concentration in liver and kidney of diabetic rats (Ravi et al., 2004). Administration of various doses of jamun seed powder into streptozotocin-induced diabetic rats has shown attrition in the fasting glucose level (Sridhar et al., 2005). Likewise, treatment of streptozotocin-induced diabetic rats with $100 \mathrm{mg} / \mathrm{kg}$ body weight seed kernel ethanol extract reduced the blood sugar level, urea and cholesterol and led to a rise in the glucose tolerance and decreased the glutamate oxaloacetate transaminase and glutamate pyruvate transaminase activities (Ravi et al. 2005). Bael (Aegle marmelos) has been used as a herbal medicine for the management of diabetes mellitus in Ayurvedic, Unani and Siddha systems of medicine in India (Choudhry et al., 2003). Bael extract, when 
administered at a dose of $250 \mathrm{mg} / \mathrm{kg}$ of body weight, shows better result than glycenamide (antidiabetic drug). This antidiabetic effect may be due to the coumarins present in the fruit which induce the beta cells of islet of Langerhans to produce insulin. Aqueous extract of bael seeds reduces blood glucose level in case of severe diabetic patients (Maity et al., 2009; Kamalakkannan and Prince, 2003). Aqueous extract of bael leaves were useful in the long-term management of diabetes due to hypoglycemic and antioxidant effect (Upadhya et al., 2004; Maity et al., 2009). Similarly, anti hyperlipidaemic activity of aqueous extract of bael fruits was demonstrated by Marinzene et al. (2005), using the streptozotocin induced diabetic. Sunderam et al. (2009) worked on alcoholic extract of bael and jamun in diabetic rats and confirmed their protective activity against laboratory induced cell necrosis. Leaf extract of bael on Alloxane induced diabetes and reported that used extract was enough capable to reduce oxidative stress by scavenging lipid peroxidation and enhancing certain anti oxidant levels which causes lowering of elevated blood glucose level (Kuttan and Sabu, 2004). Rambutan reported to have hypoglyric properties. Geraniin, an ellagitannin, a major bioactive compound isolated from the ethanolic extract of rind act as an anti hyperglycemic agent In addition to its extremely high anti oxidant activity and low pro oxidant capability. Geraniin has the potential to be developed into an anti hyperglycemic agent (Uma et al., 2011). Geraniin, one of polyphenol compounds, was used as an index to investigate the optimum condition of extraction from rambutan peel (red and yellow) in Taiwan. The highest total phenolic content found in red rambutan variety was at $1: 15(\mathrm{~g} / \mathrm{ml})$ ratio, but no significant difference for yellow rambutan. FRAP ranged in Rambutan rind ranged from $3800.25 \pm 86.49$ to $4116.5 \pm 88.41$ (ìmol $\mathrm{Fe} 2+/ \mathrm{g}$ dry weight ), flavonoid from $6.41 \pm 0.48$ to $8.57 \pm 0.35$ (mg Quercetin/g dry weight) and total phenolic recovery from $297.78 \pm 4.06$ to $358.42 \pm 4.63$ (mg GAE/g dry weight). Anti diabetic properties of jack fruit is also reported. According to a study carried out by Fernando et al. (1991), the hot water extract of jackfruit leaves significantly improved glucose tolerance in the normal subjects and the diabetic patients when investigated at oral doses equivalent to $20 \mathrm{~g} / \mathrm{kg}$. It also exhibited hemagglutination activity against human and rabbit erythrocytes. Rambutan fruit peel have antidiabetic and antihypercholesterolemic activities. The highest percentage reduction in blood glucose and cholesterol levels are shown of rambutan fruit peels extract with dose $500 \mathrm{mg} / \mathrm{kg}$ and the value of percentage reduction were $61.76 \pm 4.26 \%$ and $60.75 \pm 8.26$ (Muhtadi et al., 2016). The fruit of bilimbi has antidiabetic effect studied using streptozotocin-induced diabetic rats (Tan et al., 1996). The flavonoids, carotenoids, and terpenes could be the potent bioactive compounds in bilimbi fruits that provide the antidiabetic effect. Aqueous leaf extract of graviola to streptozotocin-induced diabetic rats sas found to reduce glucose levels treated diabetic rats along with an elevation in blood insulin (Adewole and Ojewole, 2010). Aqueous fruit rind extract of the kokum exhibited antidiabetic activity in streptozotocin-induced hyperglycemic rats (Kirana and Srinivasan, 2010).

\subsection{Antioxidant activity}

Normal metabolic activities give rise to free radicals. These free radicals, mainly oxygen free radicals, referred as ROS (Reactive Oxygen Species) causes oxidative stress. ROS are harmful for the body as they damage macromolecules, DNA, proteins and lipids. Antioxidants are compounds that scavenge the free radicals and reduce oxidative stress. Bael fruit has proven to show antioxidant activity. On administration of bael fruit extract of $250 \mathrm{mg} / \mathrm{kg}$ of body weight, the activity of ROS scavengers such as glutathione peroxidase, glutathione reductase, superoxide dismutase (SOD) and catalase is shown to increase considerably. Use of above mentioned dose of bael fruit extract shows better results than glibenclamide (36 ig/ $\mathrm{kg}$ ). The antioxidant activity may be due to presence of flavonoids, alkaloids, sterols, tannins, phlobatannins and flavonoid glycosides (Kamalakkannan and Prince 2003; Singh and Malik, 2000). The rambutan unpigmented fruit flesh, does not contain significant polyphenol content, but its colorful rind displays diverse phenolic acids, such as syringic, coumaric, gallic, caffeic and ellagic acids having antioxidant activity in vitro. Ethanol extract of rambutan fruit peels 
contains ethyl gallate (Muhtadi, et al., 2016) which has the strong antioxidant activity. Ethanol extract of rambutan fruit peels are known to have a greater ability as an antioxidant to capture DPPH free radicals than vitamin E (Tamimy, 2006). In rambutan variety, ethyl acetate extract of rambutan peels had the highest DPPH scavenging activity with IC50 $3.5 \mathrm{ig} / \mathrm{mL}$, while ethyl acetate extract of binjai rambutan peels had the highest FRAP capacity with EC50 $77.1 \mathrm{ig} / \mathrm{mL}$. N-hexane extract of binjai rambutan peels had the highest total flavonoid (3.46 g QE/100 g), ethyl acetate extract of lebakbulus rambutan peels had the highest phenolic content ( $40.9 \mathrm{~g} \mathrm{GAE} / 100 \mathrm{~g}$ ) and n-hexane extract of rapiah rambutan peels had the highest carotenoid content $(0.61 \mathrm{~g} \mathrm{BE} / 100 \mathrm{~g})$. There was a positively high correlation between total phenolic content with their antioxidant activity using DPPH and FRAP assays. In rambutan peel, the extraction of antioxidant compounds, FRAP ranged from $3800.25 \pm 86.49$ to $4116.5 \pm 88.41$ (ìmol Fe2+/g D.W), flavonoid from $6.41 \pm 0.48$ to $8.57 \pm 0.35$ (mg Quercetin/g D.W), and total phenolic recovery from $297.78 \pm 4.06$ to $358.42 \pm 4.63$ (mg GAE/g D.W.) (Azaria and $\mathrm{Pi}-\mathrm{Jen}, 2015$ ). Antioxidant properties in aonla fruit exhibit due to the presence of phenolic compounds (Anila and Vijayalakshmi, 2002; Sabu and Khuttan, 2002; Kumar et al., 2006). Total polyphenolic content of different aonla varieties fresh fruits ranged from 70.6 to $159.4 \mathrm{mg} \mathrm{GAE} / \mathrm{g}$. Significant difference $(p<0.05)$ was observed in total polyphenol content of different varieties. Similarly, total polyphenol content in aonla powders varied from 90.5 to $385 \mathrm{mg} / \mathrm{g}$, showed significant $(p<0.05)$ varietal difference. Jamun fruit has been reported for strong antioxidant and anti-genotoxic potential. Different parts of this plant are used in herbal formulations. The pulp of the fruit contains diglucoside of five anthocyanidins (Arun et al., 2011; Li et al., 2009). Anthocyanins exhibit anticarcinogenic properties such as induction of cell-cycle arrest and apoptosis, as well as the inhibition of tumor formation and growth in animals (Sabu and Khuttan, 2002). Kokum fruit has high antioxidant properties (Krishnamurthy and Sampathu, 1988; Mishra et al., 2006). Choloroform extracts of $G$. indica fruit rinds exhibited excellent antioxidant activities in â-carotene-linoleate and DPPH assays (Tamilselvi et al., 2003). Aqueous extracts of G.indica fruits acts as very good antioxidants as evident from their DPPH and lipid peroxidation assays. Aqueous extracts of kokum inhibit ascorbate-Fe2+ induced lipid peroxidation in rat liver mitochondrial fractions (Mishra et al., 2006). Organic acids like citric acid and malic acid from $G$. indica also acts as good antioxidants (Swami et al, 2014). G. indica bark exudates showed its total phenol and xanthone content as $53.43 \mathrm{~g} / 100 \mathrm{~g}$ and $32.42 \mathrm{~g} / 100 \mathrm{~g}$ respectively, revealing it as a potential source of antioxidants (Parthasarathy and Nandakishore, 2016). Palakawong et al. (2010) have evaluated the 50\% ethanolic extracts of peel, leaves, and bark of mangosteen and found that the highest antiradical activities using DPPH radicals with IC50 of 5.94 $\mathrm{ig} / \mathrm{ml}$, followed by bark 6.46 and leaves $9.44 \mathrm{ig} /$ $\mathrm{ml}$. Ethanol and $\mathrm{n}$-hexane extract of karonda fruits showed significant antioxidant activities in both extracts compared to ascorbic acid, ASA and tertbutyl- 1-hydroxytoluene (BHT) in 2,2-diphenyl1-picrylhydrazyl (DPPH) free radical scavenging with IC of 1.44 and $1.98 \mathrm{ig} / \mathrm{ml}$ of ethanolic extract and $\mathrm{n}$-hexane extract, respectively. Total antioxidant activity and total phenolic content in karonda fruit were comparable to vincristine sulfate, having IC values of 3.43 and 2.66 of ethanolic extract and $n$-hexane extract, respectively.

\subsection{Anticancer activity}

Several mnoir fruits have anticarcenogenic properties. Extracts of different plants of sour sop (Annona muricata) are well known for their medicinal values. It has been found that the compound present have a variety of anticancer effects including cytotoxicity (Zeng et al., 1995; Kim et al., 1998), induction of apoptosis (Eggadi et al., 2014), necrosis (Torres et al., 2012), and inhibition of proliferation on a variety of cancer cell lines, including breast, prostate, colorectal, lung, leukemia, renal, pancreatic, hepatic, oral, melanoma, cervical and ovarian cancers. The bark, fruit, leaves, root, and seeds, are used as natural medicines in the tropics (Adewole and Ojewole, 2010). The study on methonlic extracts of leaves of jack fruit showed inhibitory effect on various cariogenic bacteria (Sato et al., 1996). The extracts of bael for cytotoxic action using brine shrimp lethality assay; sea urchin eggs assay, and MTT 
assay using tumour cell lines. The extract of Aegle marmelos was found to exhibited toxicity on all used assays (Leticia and Costa, 2005). Anticancer effect of hydroalcoholic extract of bael leaves in the animal model of Ehrlich ascites carcinoma and proposed that induction of apoptosis may be due the presence of Skimmianine in extract (Jagetia et al., 2005). The anthocyanin i.e., cyanidin-3glucoside present in kokum fruits decreased the number of non-malignant and malignant skin tumours in the two staged skin carcinogenesis and also caused a dose-dependent inhibitory effect on the migration and invasion of metastatic A549 human lung carcinoma cells (Ding et al., 2006). In extract of fruits of karonda was found effective for breast cancer. Free radical scavenging and anticancer activity analysed by DPPH and MTT assays; invasive ductal carcinoma breast cancer protein -aromatase was selected as target which is an oestrogen-synthesising enzyme. IC50 concentration of extract was $86.7308(\mu \mathrm{g} / \mathrm{ml})$ found effective against MCF-7 cell lines (Kiruthika et al., 2019). Decoction of fruits of passion fruit was found inhibiting activity of gelatinase matrix metalloproteinases (MMP-2 and MMP-9), two metallo-proteases involved in the tumour invasion, metastasis and angiogenesis (Puricelli et al., 2003).

\subsection{Anti microbial properties}

The ethnolic extract of dried fruit pulp of bael was found effective against various intestinal pathogens i.e. Shigella boydii, S. sonnei \& S. Flexneri. This was due to presence of certain phytochemicals such as phenols, tannins and flavonoids (Maheshwari et al., 2009). It was also confirmed by Kaur et al. (2009) by getting treat $E$. Coli with bael fruit extract. Citarasu et al. (2003) found positive bactericidal effects of bael on certain pathogenic bacteria like Salmonella typhi, Pseudomonas aeruginosa, Aeromonas hydrophyla and Vibrio sp. The rambutan peel extract exhibited antibacterial activity against five pathogenic bacteria. The most sensitive strain, Staphylococcus epidermidis, was inhibited by the methanolic extract (MIC $2.0 \mathrm{mg} / \mathrm{mL}$ ) (Fidrianny 2015). The methanolic extracts of stem, roots, bark and leaves and seeds of jack fruit exhibit broad spectrum antibacterial properties against various gram positive and negative bacteria (Jagtap and Bapat,
2010; 2013). However the butanol fractions of root bark and fruit have much promising antibacterial activity (Khan et al., 2003). Methanolic extracts of the stem and root, barks, heartwood, leaves, fruits, and seeds of jackfruit have exhibited abroad spectrum of antibacterial activity (Khan et al., 2003). Aqueous and methanol extracts of Garcinia indica leaves and fruit rinds showed antibacterial activity against Salmonella species (Pasha et al., 2009). Methanol and petroleum ether extracts of both roots and fruits of Carisaa carandas compared with standard drug ciprofloxacin (antibacterial activity) and fluconazole (antifungal activity) (Mishra et al., 2009). G. xanthochymus showed prominent zones of inhibition against Vibrio cholera, Salmonella typhimurium, Shigella flexnerii, Streptococcus pyrogens, Streptococcus mutans and Candida parapsilosis (Murmu et al., 2016).

\subsection{Anti-inflammatory activity}

The extract of leaves of bael have antiinflammatory, antipyretic \& analgesic and the extract caused a significant inhibition of the carrageenan-induced paw oedema and cotton-pellet granuloma in rats (Arul et al., 2005). Ghangale (2008) evaluated aqueous extract of bael for anti inflammatory activity by using rat paw oedema model and found anti-inflammatory activity. Shankharananth (2007) found that methanolic extract of leaves of bael@200 and 300 mg/kgBW show significant analgesic activity on acetic acid induced writhing and tail flick test in mice. Rambutan is reported to have many biological activities (Suganthi and Josephine, 2016; Nethaji et al., 2015). The study of anti-inflammatory activities of the aqueous extract of the peel of rambutan $c v$. Malwana special revealed that total phenolic content and the total flavonoid content of AEPR were 463.5 $\pm 5.2 \mathrm{mg}$ (PGE)/g and $375.0 \pm 13.2$ $\mathrm{mg}(\mathrm{QE}) / \mathrm{g}$ respectively. The 2, 2-diphenyl-1picrylhydrazyl (DPPH) radical scavenging activity of AEPR was 3.9-64.5\% for concentrations of 10 $500 \mathrm{ig} / \mathrm{ml}$. The hydroxyl radical scavenging activity of AEPR ranged from 10.3-35.0\% for concentrations of $1000-1500 \mathrm{ppm}$. The protection reported for Human Red Blood Cell (HRBC) assay was 17.1-34.8\% for concentrations from 35.5-250.0 ppm. Aspirin protection ranged from 32.3-54.5\%. 
These results show that the AEPR prepared from peelwaste has a potential to be used as an antioxidant and also it possesses anti-inflammatory activity (Uduwela et al., 2019). The antiinflammatory effects of methanol extract of dried fruits of karonda@400 mg $/ \mathrm{kg}$ showed significant inhibition of paw volumein carrageenan-induced hind paw oedema in rats (Anupama et al., 2014).

\subsection{Antifungal activity}

Kokum rind extract showed antifungal effects against Candida albicans, Penicillium sp. and Aspergillus flavus (Varalakshmi et al., 2010; Tamilselvi et al., 2003). An anti fungal protein was isloted from passion fruit seed. The iso-lated 67$\mathrm{kDa}$ protein, designated as passiflin, exhibited an $\mathrm{N}$-terminal amino acid sequence closely resembling that of bovine beta-lactoglobulin (Lam \& Ng, 2009). Patil (2009) reported the antifungal activity of ethanolic extract of the bael leaves. Rana (1997) evaluated anti fungal activity of essential oils isolated from the leaves of bael using spore germination assay. The oil exhibited variable efficacy against different fungal isolates and $100 \%$ inhibition of spore germination of all the fungi tested. It was proposed that from bael leaf essential oil may interfere with the Ca-dipicolonic acid metabolism pathway and possibly inhibit the spore formation. Pitre and Srivastava (1987), demonstrate the antifungal activity of ethanolic root extract against Aspergillus fumiganus and Trichphyton mentagrophytes. Jackfruit is also known for its antifungal properties. The studies of jackfruit seeds shown to inhibit growth of Fusarium moniliforme and Saccharomyces cerevisiae (Trinade et al., 2006). It was found that a chitin-binding lectin namedjackin present in the seeds has ability to inhibit the growth of Fusarium moniliforme and Saccharomyces cerevisiae.

\subsection{Hyperlipidemic activity}

Hydroxy citric acid is the main active ingredient of most of the species of genus Garcinia. It acts in inhibiting the recapture of serotonin, inhibiting acetylcholinesterase, increasing the oxidation of fatty acids, and reducing lipogenesis. The lipid levels were maintained at near normalcy when cotreated with Garcinia cambogia extract in dexamethasone administered rats (Mahendran and Devi, 2001). Garcinia cambogia showed an antiobesity effect and a significant reduction in the values of triacylglycerol (TAG) of the adipose tissue and liver of the tested groups; however, it significantly increased the TAG pool of the gastrointestinal system. The antiobesity effect and significant reduction of triacylglycerol was also exhibited by aqueous extract of the rind of kokum fruits. Aqueous extract of Carissa carandas has been investigated for lipid-lowering activity in egg yolk-induced hyperlipidemic rats. The researchers concluded that the extract exhibited a significant reduction in body weight, cholesterol, triglycerides, high-density lipoprotein (HDL) and low-density lipoprotein (LDL) in model-induced rats. All the results were compared with the standard drug, atorvastatin. Even the histopathological changes in high-cholesterol diet have been reduced significantly with the extract (Sumbul and Ahmed, 2012).

\subsection{Hepatoprotective activity}

Singanan et al. (2007) worked on bael leaf extract on alcohol induced liver injury in albino rats and presented data of excellent hepatoprotective effects. Similarly, Ramnik Singh and Rao (2008) also demontrated that aqueous extarct of bael fruit pulp and seeds are effective in the treatment and prevention of $\mathrm{CCl} 4$ induced hepatic toxicity. Methanolic extract of karonda leaves showed hepatoprotective activity using carbon tetrachloride-induced hepatotoxicity in albino rats. The results was as effective as silymarin-treated animals (Bhati et al., 2014).

\subsection{Antiulcer activity}

Oral administration of pyranocoumarin isolated from the seeds of bael showed significant protection against pylorus-ligated and aspirin-induced gastric ulcers in rats and cold restraint stress-induced gastric ulcers in rats and guinea pigs (Goel,1997; Dhuley, 2004) reported that pretreatment of rats with unripe bael fruit extract produce a significant inhibition of absolute ethanol induced gastric mucosal damage. The anti-ulcer activity had examined with different extracts of karonda using petroleum ether, chloroform, alcohol applied on different models using acetic acid-induced chronic gastric ulcer, pylorus ligation and even ethanolinduced acute gastric ulcer, respectively. Oral administration of $500 \mathrm{mg} / \mathrm{kg}$ of all extracts would 
have enhanced the healing of acetic acid-induced chronic gastric ulcers. Among all the extracts, alcoholic extract showed significant activity in pylorus ligation and stress-induced ulcer. It is concluded that the alcoholic extract of the plant would possess highly potent effect when compared to other extracts (Merai and Jadhav, 2014).

\subsection{Anti thyroid activity}

Panda and Kar (2006) isolated scopoletin (7hydroxy-6-methoxy coumarin) from bael leaves and evaluate for its potential to regulate hyperthyroidism. It was observed that scopoletin (at $1.00 \mathrm{mg} / \mathrm{kg}$, p.o. for 7 days) to levo-thyroxine treated animals, decreased serum thyroid hormones level. It was also proved that the scopoletin have superior therapeutic activity than the standard antithyroid drug, propylthiouracil.

\subsection{Antinociceptive and anthelmintic activity}

Methanol leaf extract of crude drug was investigated for antinociceptive, anthelmintic and cytotoxic activities. Antinociceptive effect of Carissa carandas was determinedusing acetic acidinduced writhing assay in Swiss albinomice, whereas in case of anthelmintic activity, the fresh juice of plant leaves was evaluated by recording the time duration of paralysis and the death of Pheretima posthuma, earthworms. The cytotoxic activity of methanolleaf extract was analysed using brine shrimp lethality bioassay. Results revealed the potency of the plant that it possesses significant antinociceptive and anthelminticactivity. Methanol leaf extract showed marked cytotoxicproperty as compared with vincristine sulfate used as standard drug (Prveen, 2018).

\subsection{Antidiarrhoeal activity}

The ethanolic fruit and root extracts of Carissa carandas@200 and 400 mg/kg BW considerably reduced the total number of wet faeces, compared with standard drug, loperamide $(5 \mathrm{mg} / \mathrm{kg})$. Even the ethanol fraction of both plant parts decreased the propulsion of charcoal meal through gastrointestinal tract when compared to atropine sulfate as standard drug. Results revealed the fact that the highest doses of both the plant part extract contained similar effects (Mishra and Sasmal, 2015). In case of chronic diarrhoea and dysentery without fever, half ripe or unripe fruit of bael acts as a remedy. Half ripe fruit is considered best for the purpose but fully ripe fruits or even fruit powder has shown effective results. When the fruit is still unripe, it is cut, dried and ground into powder. The unripe fruit can also be consumed by baking and then consumption with brown sugar or jaggery. After use of fruit, the amount of blood passed in the faecal matter reduces and the faecal matter gets a more solid form (Sharma et al., 2006; Patel et al., 2012).

\section{Conclusion}

It is quite evident from this review that a minor fruits contain a number of phytoconstituents which reveals its uses for various medicinal and therapeutic purposes. The fruits and other plant parts are being used in the folk and tradiotnal medicines by the local inhibitants since long. Some the researches on the phytochemicals present in these speices are being analised and documented. The validation of these pepoerties is also in the progress for the treatment of various disorders in human being such as, diabetes, liver toxicity, fungal infection, microbial infection, inflammation, pyrexia and to relieve pain. Although a part of these fruits have been studied for their medicinal properties, substantial scientific data is still lacking and theresearches are still at a very preliminary stage. Still, very few fruits ahve been studied and most of the much work is required to csriied out in most of these fruits. As the global trends on plant based medicines is radidly growing. The studies need to be performed for the fruits to investigate the mechanism of actions with other therapeutic activities.

\section{REFERENCES :}

Achrekar, A, Kaklij G.S., Pote, M.S., Kelkar, S.M. 1991. Hypoglycemic activity of Eugenia jambolana and Ficus bengalensis: mechanism of action. In vivo., 5(2):143-147.

Adewole S. and Ojewole, J. 2010. Protective effects of Annona muricata linn. (Annonaceae) leaf aqueous extract on serum lipid profiles and oxidative stress in hepatocytes of streptozotocin-treated diabetic rats. African Journal of Traditional, Complementary and Alternative Medicines, 6(1) doi: 10.4314/ajtcam. v6i1.57071 
Ahmad, I. and Beg, A. Z. 2001. Antimicrobial and phytochemicalstudies on 45 Indian medicinal plants against multi-drugresistant human pathogens. Journal of Ethnopharmacology, 74(2):113-123.

Ambili, S., Subramoniam, A. and N. S. Nagarajan. 2009. Studies on the antihyperlipidemic properties of Averrhoa bilimbi fruit in rats, Planta Medica, 75(1): 55-58.

Amin, Henna, Wakode, Sharad and Tonk. Rajeev Kumar. 2017 Feronia Limonia -A Wonder Drug, World Journal of Pharmacy and Pharmaceutical Sciences, 6(4): 1982- 1994.

Anila, L. and Vijayalakshmi, N.R. 2002. Flavonoids from Emblica officinalis and Mangifera indica- effectiveness for dyslipidemia. J Ethnopharmacol., 79: 8187.

Anonymous.2019. Fruit: world production by type 2019. Statista, https://www.statista.com > Agriculture > Farming

Anupama, N., Madhumitha, G. and Rajesh, K. S. 2014. Role of dried fruits of Carissa carandas as anti-inflammatory agents and the analysis of phytochemical constituents by GC-MS.BioMed Research International, vol. 2014, Article ID 512369, 6 pages https://doi.org/10.1155/2014/ 512369 .

Arul, V., Miyazaki, S and Dhananjayan, R. 2005. Studies on the anti-inflammatory, antipyretic and analgesic properties of the leaves of Aegle marmelos Corr. Journal of Ethnopharmacology, 96 (4):159-163.

Arul, V., Miyazaki, S. and Dhananjayan, R.2004. Mechanisms of the contractile effect of the alcoholic extract of Aegle marmelos Corr. on isolated guinea pig ileum and tracheal chain. Phytomedicine, 11: 679-683.

Arun, R., Prakash, M.V., Abraham, S.K. and Premkumar, K. 2011.Role of Syzygium cumini seed extract in the chemoprevention of in vivo genomic damage and oxidative stress. J Ethnopharmacol, 134:329-333.

Arung, E. T., Shimizu, K. and Kondo, R. 2007. Structure-activityrelationship of prenylsubstituted polyphenols from Artocarp usheterophyllus as inhibitors of melanin biosynthesis in cultured melanoma cells. Chem Biodivers., 4(9):2166-71.
Aruoma, O.I., 1998. Free radicals, oxidative stress, and antioxidants in human health and disease. J. Am. Oil Chem. Soc., 75 (2), 199-212.

Ashrafuzzaman, M. Most. Morsada Khatun, Noshin A. Tunazzina and A.K.M. Golam Sarwar. 2021. Conservation of minor fruit genetic resources at the Botanical Garden, Bangladesh Agricultural University. International Journal of Minor Fruits, Medicinal and Aromatic Plants, 7 (1): 1-18.

Ayyanar, M. 2008. Ethnobotanical wealth of Kani tribe in Tirunelveli hills (Ph.D thesis) University of Madras, Chennai, India.

Azaria Gusman, J. and Pi-Jen, T. 2015. Extraction of antioxidant compounds from rambutan (Nephelium lappaceum L.) peel as agricultural waste in Taiwan. J. Trop. Crop Sci., 2: 10-16.

Badam, L., Bedekar, S.S., Sonawane, K.B., Kiran, B. and Joshi, S.P. 2002. In vitro antiviral activity of bael (Aegle marmelos Corr) upon human coxsackieviruses B1- B6. Journal of Communicable Diseases, 34(2): 88-99.

Baggett, S., Protiva, P., Mazzola, .EP., Yang, H., Ressler, E.T., Basile, M.J., Bernard Weinstein I. and Kennelly, Edward J.. 2005.. Bioactive benzophenones from Garcinia xanthochymus fruits. J Nat Prod., 68:354-360.

Baishya, R.A., Sharma, J. and Begum A.2013. Forest based medicinal plants rendering their services to the rural community of Assam, India. Int J Appl Biol Pharm Technol., 4:1020.

Baliga, M.S., Bhat, H.P., Pai, R.J., Boloor, R. and Princy, L.P. 2011. The chemistry and medicinal uses of the underutilized Indian fruit tree Garcinia indica Choisy (kokum): A review. Food Res. Int., 44: 1790-1799.

Barbosa, P.R., Valvassori, S.S., Bordignon, C.L.J., Kappel, V.D., Martins, M.R., Gavioli, E.C., Quevedo, J. and Regi-natto, F.H. 2008. The aqueous extracts of Passiflora alata and Passiflora edulis reduce anxiety-related behaviours without affecting memory process in rats. J. Med Food, 11(2): 282-288.

Barik, B.R., Bhaumik, T. A.K. and Kundu, A.B.1997. Triterpenoids of Artocarpus heterophyllus, J. Indian Chemical Soc. 74: 163-164. 
Barthakur, N.N.and Arnold, N.P.1989. Cetrain organic and inorganic constituents in bael (Aegle marmelos) fruit. Tropical Agriculture (Trinidad), 66: 65-68.

Basu, D. and Sen, R. 1974. Alkaloids and coumarins from root-bark of Aegle marmelos. Phytochemistry, 13: 2329-2330.

Benherlal, P.S. and Arumughan,C. 2007. Chemical composition and in vitro antioxidant studies on Syzygium cumini fruit. J Sci Food Agric., 87:2560-2569.

Bhandary, M.J, Chandrashekar, K.R, and Kaveriappa, K.M. 1995. Medical ethnobotany of the Siddis of Uttara Kannada district Karnataka India. J. Ethnopharmacol., 47:149-158.

Bhandary, M.J, Chandrashekar, K.R, and Kaveriappa, K.M. 1995. Medical ethnobotany of the Siddis of Uttara Kannada district Karnataka India. J. Ethnopharmacol., 47:149-158.

Bhargava, K.K., Dayal, R. and Seshadri, T.R.1974. Chemical components of Eugenia jambolana stem bark. Curr Sci., 43: 645646.

Bhati, P, Shukla, Ajay, Sharma, Maya and Mourya, Pramod. 2014. Hepatoprotective activity of leaves extracts of Carissa carandas. Indo American Journal of Pharmaceutical Research, 4(11): 5185-5192.

Bhatia A. and Mishra, T. 2010. Hypoglycemic activity of Ziziphus mauritiana aqueous ethanol seed extract in alloxan-induced diabetic mice. Pharmaceutical Biology, 48 (6): 604-610.

Bhatia, I.S. and Bajaj, K.L. 1975. Chemical constituents of the seeds and bark of Syzygium cumini. Plant Med., 28: $347-$ 352.

Bhatia, I.S., Sharma, S.K. and Bajaj, K.L.1974. Esterase and galloyl carboxylase from Eugenia jambolana leaves. Indian $J$ Exp Biol., 12: 550-552.

Bhattacharya, S., Chaudhuri, S. R., Chattopadhyay, S. and Bandyopadhyay, S. K. 2007. Healing properties of some Indian medicinal plants against indomethacin-induced gastric ulceration of rats, Journal of Clinical Biochemistry and Nutrition, 41(2): 106-114.
Bisset, NG. 1994. Herbal Drugs and Phytopharmaceuticals. Boca Raton, FL: CRC Press.

Blomhoff, R. 2005. Dietary antioxidants and cardiovascular disease. Current Opinion in Lipidology, 16(1): 47-54.

Bombardelli, E., Bonati, A., Gabetta, B., Martinelli, E. and Mustich, G.1975. Passiflorine- A new glycoside from Passiflora edulis. Phytochemistry, 14: 2661-2665.

Braga, F.G, Bouzada, M.L.M., Fabri, R.L., Matos, M.O., Moreira, F.O., Scio, E. and Coimbra Elaine S. 2007. Antileishmanial and antifungal activity of plants used in traditional medicine in Brazil. J Ethnopharmacol., 111:396-402.

Brahmachari, H.D. and Augusti, K.T. 1961. Hypoglycemic agents from Indian indigenous plants. J Pharm Pharmacol., 13:381-182.

Chaivisuthangkura, A., Malaikaew, Y., Chaovanalikit, A., Jaratrungtawee, A., Panseeta, P. and Ratananukul, P. 2009. Prenylated xanthone composition of Garcinia mangostana (mangosteen) fruit hull. Chromatographia, 69: 315-318.

Chakthong, S., Weaaryee, P., Puangphet, P., Mahabusarakam, W., Plodpai, P., Voravuthikunchai, S.P. and Kanjana-Opas, A. 2012. Alkaloid and coumarins from the green fruits of Aegle marmelos. Phytochemistry, 75: 108-113.

Chatterjee, A. and Mitra, S.S.1949. On the constitution of the active principles isolated from the matured bark of Aegle marmelos correa. Journal of the American Chemical Society, 71(2): 606-609.

Chattopadhyay, S.K. and Kumar, S. 2006. Identification and quantification of two biologically active polyisoprenylated benzophenones xanthochymol and isoxantho chymol in Garcinia species using liquid chromatography-tandem mass spectrometry. J. Chromatogr. B, 844 (1), 67-83.

Chawdhary, F.A. and Raman, M.A. 1997. Distribution of free sugars and Fatty acids in Jackfruit. Food chemistry, 60(1): 25-28.

Chhetri, D.R., Parajuli, P. and Subba, G.C. 2005.Antidiabetic plants used by Sikkim and Darjeeling Himalayan tribes, India. $J$. Ethnopharmacol., 99:199-202. 
Chopra, R. N., Nayer, S. L. and Chopra I. C.1992. Glossary of Indian Medicinal Plant, Council of Scientific and Industrial Research, New Delhi, India.

Choudhry, B.K., Kar, A. and Bandhopadhyay, N.G. 2003. Comparative evaluation of hypoglycemic activity of some Indian medicinal plants in alloxan diabetic rats. Journal of Ethnopharmacology, 84:105-108.

Chun-Nan Lin and Chai-Ming Lu.1993. Heterophylol, a phenolic compound with novel skeleton from Artocarpus heterophyllus, Tetrahedron letters, 34 (17): 8249-8250.

Citarasu, T., Rajajeyasekar, R., Venkatmalingam K., Dhandapani, P. S and Peter Marian 2003. Effect of wood apple Aegle marmelos Correa (Diacotyledons, Sapindales, Rutaceae) Extract as an antibacterial agent on pathogens infecting prawn (Penaeus indicus) larviculture. Indian Journal of Marine Science, 32 (2):156-161.

Cotterill ,P. J. and Scheinmann, F. 1977. Phenolic Compounds from the Heartwood of Garcinia indica. Phytochemistry, 16: 148-149.

Cox, P. A. 1993. Saving the ethnopharmacological heritage of Samoa," Journal of Ethnopharmacology, 38 (2-3):181-188.

Cui J, Hu W,, Cai, Z, Liu, Y, Li, S, Tao, W. and Xiang, H. 210.New medicinal properties of mangostins: analgesic activity and pharmacological characterization of active ingredients from the fruit hull of Garcinia mangostana L. Pharmacol Biochem Behavior, 95:166-172.

Dalee, A. D., Mukhurah, S., Sali, K., Hayeeyusoh, N., Hajiwangoh, Z. and Salaeh, P. 2015. Antimicrobial substances from endophyticfungi in tamarind (Tamarindus indica Linn), malay apple (Eugenia malaccensis, Linn), rambutan (Nephelium lappaceum), and Indian mulberry (Morinda citrifolia, Linn)," in Proceedings of the International Conference on Research, Implementation and Education of Mathematics and Sciences., May 17-19 at Faculty of Mathematics and Natural Science, Yogyakarta State University, Yogyakarta, Indonesia, Page B-1-B-16.
Das, Anuradha. 2021. Ethno-medicines used by Santals \& Paharias for treating skin diseases. International Journal of Minor Fruits, Medicinal and Aromatic Plant, 7(1): 89-97.

Das, S., Das, S. and De, B. 2012. In vitro inhibition of key enzymes related todiabetes by the aqueous extracts of some fruits of West Bengal, India. Current Nutrition and Food Science, 8(1): 19-24.

Dayal, R. and Seshadri, T.R.1974. Colourless compounds of the roots of Artocarpus heterophyllus. isolation of new compound artoflavone. Indian J Chem., 12: 895-896.

de Albuquerque, U.P., Muniz de Medeiros, P, de Almeida, A.L., Monteiro, J.M., Machado de Freitas Lins Neto, E, Gomes de Melo, J., et al. 2007. Medicinal plants of the caatinga (semi-arid) vegetation of NE Brazil: a quantitative Ethnopharmacol., 114:325-354.

Dhawan, K., Dhawan, S.and Sharma, A. 2004. Passiflora: a review update, $J$ Ethnopharmacol, 94: 1-23.

Dhuley, J. N.2004. Investigation on the gastroprotective and antidiarrhoeal properties of Aegle marmelos unripe fruit extract, Hindustan Antibiot Bull, 45-46 : 41-46.

Dhuley, J. N.2004. Investigation on the gastroprotective and antidiarrhoeal properties of Aegle marmelos unripe fruit extract, Hindustan Antibiot Bull., 45-46 : 41-46.

Ding, M., Feng R., Wang, S.Y., Bowman, L., Lu, Y., Qian, Y., Castranova, V., Jiang, B.H. and Shi, X. 2006. Cyanidin-3-glucoside, a natural product derived from blackberry, exhibits chemopreventive and chemotherapeutic activity. J. Biol. Chem, 281: 17359-17368.

Doka, I.G., Tigani, E.1., Yagi, S. 2014. Amino acid content, fatty acid profile and radical scavenging capacities of Coccinia grandis (L.) Voigt. Fruits. Adv. J. Food Sci. Technol. 6(12): 1307-1312.

Ebbo, A.A., Mammam, M., Suleiman, M.M., Ahmed, A. and Bello, A. 2014. Preliminary phytochemical screening of Diospyros mespiliformis. Anat Physiol., 4: 156. doi:10.4172/2161-0940.1000156. 
Ediriweera, E. R. H. S. S. and Ratnasooriya, W. D. 2009. A review on herbs used in treatment of diabetes mellitus by Sri Langkan ayurvedic and traditional physicians, $A Y U$ ( $A n$ International Quarterly Journal of Research in Ayurveda), 30 (4):373-391.

Eggadi V., Gundamedi, S., Sheshagiri, S. B. B., Revoori, S. K., Jupally V. R. and Kulandaivelu, U. 2014. Evaluation of anticancer activity of Annona muricata in 1, 2-dimethyl hydrazine induced colon cancer. World Applied Sciences Journal, 32 (3): 444-450.

Farooq, S. 2005. Medicinal plants- Field and laboratory manual. International Book Distributers, Dehradun.

Fernando, M. R., Wickramasinghe, M., Thabrew, I., Ariyananda, P.L. and Karunanayake, E. H. 1991. Effect of Artocarpus heterophyllus and Asteracanthus longifolia on glucose tolerancein normal human subjects and in maturity-onset diabeticpatients, Journal of Ethnopharmacology, 31 (3): 277-282.

Fidrianny,I., Sari, P.I. and Wirasutisna, K.R. 2015. Antioxidant activities in various peel extracts of four varieties of rambutan (Naphalium lappaceum) using DPPH,FRAP assays. Int.J. pharmcog. Phytochem.Res.,7:280-280.

Ghangale G. R., Surve V. S., Anbarasan K. and Gatne M. M. 2008. Evaluation of Aegle marmelos (Bael) for anti-inflammatory activity in rats. The Journal of Bombay Veterinary College, 16(1): 15-16.

Goel, R. K., Maiti, R .N., Manickam, M. and Ray, A. B. 1997. Antiulcer activity of naturally occurring pyrano-coumarin and isocoumarins and their effect on prostanoid synthesis using human colonic mucosa, Indian J Exp Biol, 35: 1080.

Gorinstein, S., Poovarodom, S., Leontowicz, H., Leontowicz, M., Namiesnik, J., Vearasilp, S., Haruenkit, R., Ruamsuke, P., Katrich, E. And Tashma, Z. 2011. Antioxidant properties and bioactive constituents of some rare exotic Thai fruits and comparison with conventional fruits In vitro and in vivo studies. Food Res. Int., 44:2222-32.
Goyal, M., Sasmal, D. and Nagori, B. P. 2012. Review on ethnomedicinaluses, pharmacological activity and phytochemicalconstituents of Ziziphus mauritiana ( $Z$. jujuba Lam., non Mill). Spatula DD, 2(2):107-116.

Goyal, P.K. 2012. Phytochemical and pharmacological properties of the genus Grewia: A review. Int. J. Pharm. Pharm. Sci., 4(4):72-78.

Grover, J.K, Vats, V, and Rathi, S.S. and Dawar, R. 2001. Traditional Indian anti-diabetic plants attenuate progression of renal damage in streptozotocin induced diabetic mice. $J$. Ethnopharmacol., 76(3): 233-238.

Gupta, A. K. and Tandon, N. 2001. Review on Indian Medicinal Plants, Indian Council of Medical Research, New Delhi.

Gupta, A. K. and Tandon, N. 2004. Review on Indian Medicinal Plants, (Indian Council of Medical Research, New Delhi, pp. 182-200.

Gupta, G.S. and Sharma, D.P. 1974. Triterpenoid and other constituents of Eugenia jambolana leaves. Phytochemistry, 13: 2013 -2014.

Gupta, Ritu. 2016. Ethnobotanical studies of Bael (Aegle marmelos): A sacred plant of Hindus. International Journal of Herbal Medicine, 4(4): 114-115.

Hema, C.G and Lalithakumari, K. 1999. Screening of Pharmacological actions of Aegle marmelos. Indian J. Pharmac., 20:.80-85.

Hemborn, P. P. 1996. Contact therapy practiced by Mundas Chotanagar (Bihar). Ethanobotany. 8: 36-39.

Hemshekhar, M., K. Sunitha, M. S. Santhosh , Devaraja, s K. Kemparaju, K Vishwanath, B. S.Niranjana, S. R. and Girish, K. S. 2011. An overview on genus Garcinia: phytochemical and therapeutical aspects, Phytochemistry Reviews, 10(3): 325-351.

Hemshekhar, M., K. Sunitha, M. S. Santhosh, Devaraja, S., Kemparaju, K., Vishwanath, B.S., Niranjana, S.R. and K. S. Girish, K.S.2011. An overview on genus Garcinia: phytochemical and therapeutical aspects, Phytochemistry Reviews, 10(3): 325351 . 
Hock, Eng Khoo, Azrina Azlan, Kin Weng Kong and Amin Ismail. 2016. Phytochemicals and medicinal properties of indigenous tropical fruits with potential for commercial development, Evidence-Based Complementary and Alternative Medicine, Article ID 7591951, 20 pages. https://doi.org/ 10.1155/2016/7591951

Hosamani, K.M., Hiremath, V.B. and Keri, R.S. 2009. Renewable energy sources from Michelia champaca and Garcinia indica seed oils: A rich source of oil. Biomass Bioenergy, 33: $267-270$.

Ibragic, S. and Sofic, E. 2015. Chemical composition of various Ephedra species. Bosn. J. Basic Med. Sci., 15 (3): 21-27.

Iinuma, M., Ito, T., Miyake, R., Tosa, H., Tanaka, T. and Chelladurai, V. 1998. A xanthone from Garcinia cambogia. Phytochemistry, 47: 1169-1170.

Ilango, K. and Chitra, V. 2010. Wound Healing and Anti-oxidant Activities of the Fruit Pulp of Limonia Acidissima Linn (Rutaceae) in Rats. Tropical Journal of Pharmaceutical Research, 9(3): 223-230.

Jagetia, G.C., Venkatesh, P,, Baliga, M.S. 2005. Aegle marmelos (L.) Correa inhibits the proliferation of transplanted Ehrlich ascites carcinoma in mice. Biol Pharm Bull., 28(1):58-64.

Jagtap, U.B. and Bapat, V.A. 2010. Artocarpus: A review of its traditional uses, phytochemistry and pharmacology. Journal of Ethnopharmacology, 129 (2):142-166.

Jagtap, U.B. and Bapat, V.A. 2013. Green synthesis of silver nano particles using Artocarpus heterophyllus Lam. seed extract and its antibacterial activity. Industrial Crops and Products, 46(1): 132-137.

Jain, A, Katewa, S.S., Galav, P.K, and Sharma, P. 2005. Medicinal plant diversity of Sitamata wildlife sanctuary Rajasthan India. $J$ Ethnopharmacol., 102:143-157.

Jain, M.C., Seshadri, T.R. 1975. Anthocyanins of Eugenia jambolana fruits. Indian J Chem., 3:20-23.

IJMFM\&AP, Vol. 7 No. 2, 2021
Jantan, I., Jumuddin, F. A., Saputri, F. C and Rahman, K. 2011. Inhibitory effects of the extracts of Garcinia species on human lowdensity lipoprotein peroxidation and platelet aggregation in relation to their total phenolic contents. Journal of Medicinal Plants Research, 5(13): 2699-2709.

Jantan, I., Rafi, A. A. I. and J. Jalil, 2005. Plateletactivating factor (PAF) receptor-binding antagonist activity of Malaysian medicinal plants, Phytomedicine, 12(1-2): 88-92.

Jayaprakasha, G.K. and , K.K. 2002. Determination of organic acids in leaves and rinds of Garcinia indica (Desr.) by LC. J. Pharm. Biomed. Anal., 28: 379-384.

Jeyarani, T. and Yella Reddy, S. 1999. Heatresistant cocoa butter extenders from mahua (Madhuca latifolia) and kokum (Garcinia indica) fats. J. American Oil Chem. Soc., 76 (12): 1431-1436.

Joseph, K.S., Laxmi, V., Dandin, S. and Hosakatte, N.M. 2016. Chemistry and biological activity of Garcinia xanthochymus: A Review. JBAPN. , 6:173-194.

Joshi, P. 1986. Fish stupefying plants employed by tribals of southern Rajasthan- a Probe. Curr. Sci, 55: 647-650.

Kakiuchi, N., Senaratne, L.R.E., Huang, S.L., Yang, X., Hattori, M., Pilapitiya, U. and Namba, T. 1991. Effects of Constituents of Beli (Aegle marmelos) on Spontaneous Beating and Calcium-Paradox of Myocardial Cells. Planta Medica, 57: 43-46.

Kamalakkannan, N, and Prince, S M. P. 2003. Effect of Aegle marmelos Correa. (Bael) fruit extract on tissue antioxidants in streptozotocin diabetic rats. Ind. J. Exp. Biol., 41:1285-1288.

Kapadia, G. J. and G. S. Rao, 2011. Antimicrobial and other biological effects of Garcinia plants used in food and herbal medicine, In: Natural Antimicrobials in Food Safety and Quality, CABI, New York, USA, pp. 304-327.

Kaunda, J.S. and Zhang,Y. J. 2017. The genus Carissa: an ethnopharma cological, phytochemical and pharmacological review. Nat Products Bioprospect, 7: 181199. 
Kaur, R., Chattopadhyay, S.K., Tandon, S. and Sharma, S. 2012. Large scale extraction of thefr uits of Garcinia indica for the isolation of new and known polyisoprenylated benzophenone derivatives. Ind. Crop. Prod., 37:420-426.

Kaur, S., Kaur, P., Walia, A. and Kumar, S. 2009. Antigenotoxic activity of polyphenolic rich extracts from Aegle marmelos (L.) Correa in human blood lymphocytes and E.coli PQ 37. Rec. Nat. Prod., 3(1): 68-75.

Kedar, P. and Chakrabarti, C.H. 1983. Effects of Jambolan seed treatment on blood sugar, lipids and urea in streptozotocin induced diabetes in rabbits. Ind J Physiol Pharmacol., 27(2):135-140.

Khan, K.H. 2009. Roles of Emblica officinalis in Medicine - A Review. Bot. Res. Int., 2(4): 218-228.

Khan, M.R, Omoloso, A.D. and Kihara, M. 2003. Antibacterial activity of Artocarpus heterophyllus. Fitoterapia, 74(5): 501-505.

Khare, C.P.2007. Indian medicinal plants. New York, NY: Springer.

Kim G. S., Zeng, L., Alali, F., Rogers, L. L., Wu, F. E., McLaughlin, J. L. and Sastrodihardjo, S. 1998. Two new mono-tetrahydrofuran ring acetogenins, annomuricin $\mathrm{E}$ and muricapentocin from the leaves of Annona muricata. Journal of Natural Products, 61(4): 432-436.

Kingsley, C. Agu and Okolie, Paulinus N. 2017. Proximate composition, phytochemical analysis, and in vitro antioxidant potentials of extracts of Annona muricata (Soursop). Food Sci Nutr., 5(5): 1029-1036.

Kirana, H. and Srinivasan ,B. 2010. Aqueous extract of Garcinia indica Choisy restores glutathione in type 2 diabetic rats. J. Young Pharm., 2: 265-268.

Kiruthika, S., Sangeetha Lakshmi, P. and Praveena, A. 2019. Screening of novel lead compound from Carissa carandas against breast cancer using in-vitro and in-silico methods. Int. J. Pharm. Biol. Sci., 9: 1046-1052.

Kopanski, L. and Schnelle, G.1988. Isolation of bergenin from barks of Syzygium cumini. Plant Med., 54:572.
Krishnamurthy, N. and Sampathu, S.R. 1988. Antioxidant principles of kokum rind. J. Food Sci. Tech., 25(1): 44-45.

Krishnamurthy, N., Lewis, Y.S. and Ravindranath, B. 1982. Chemical constitution of Kokum fruit rind. J. Food Sci. Tech., 19: 97-100.

Krishnaveni, M. and Mirunalini, S. 2010.Therapeutic potential of Phyllanthus emblica (AMLA): the ayurvedic wonder, Journal of Basic and Clinical Physiology and Pharmacology, 21(1): 93-105.

Kumar, A. , Ilavarasan, R., Jayachandran, T.,Deecaraman,M., Aravindan, P., Padmanabhan, N. and Krishan, M. R. V. 2008. Anti-diabetic activity of Syzygium cumini and its isolated compound against streptozotocin-induced diabetic rats. Journal of Medicinal Plants Research, 2(9):246-249.

Kumar, A., Singh, A. and Dora, J. 2012a. Essential perspectives for Emblica offcinalis. Int. J. Pharma. Chem. Sci., 1(1): 11-18.

Kumar, G.S., Nayaka, H., Dharmesh, S.M., Salimath, P. V. 2006. Free and bound phenolic antioxidants in amla (Emblica officinalis) and turmeric (Curcuma longam) J. Food Compost Anal., 19:446-452.

Kumar, P.S.N., Gowda, D.G.B, Mantelingu, K. and Rangappa, K.S. 2013. Development and validation of a reversed-phase HPLC method for the analysis of garcinol and isogarcinol in Garcinia indica. J Pharm Res, 7:103-106.

Kumar, S., Pallavi Gupta, Virupaksha Gupta, K.L 2013. A critical review on Karamarda (Carissa carandas.Linn.). Int J Pharm Biol, 4: 637-642.

Kumar, S., Sharma, S. and Chattopadhyay, S.K. 2009. High-performance liquid chromategraphy and LC-ESI-MS method for identification and quantification of two isomeric olyisoprenylated benzophenone siso xanthochymol and camboginol in different extracts of Garcinia species. Biomed. Chromatogr., 23: 888-907.

Kuttan, R. and Sabu, M. C.2004. Antidiabetic activity of Aegle marmelos and its relationship with its antioxidant properties. Indian J. Physiol. Pharmacol., 48 (1):81-88. 
Lago, E.S., Gomes, E., da Silva, R. 2004. Extraction and anthocyanic pigment quantification of the Jamun fruit (Syzygium cumini Lam.) [Online] Available from: http/ / www.iqsc.usp. br/outros/eventos/2004/ bmcfb/trabalhos/docs/trab-76.pdf

Lam, S.K. and Ng, T.B.2009. Passiflin, a novel dimeric antifungal protein from seeds of the passion fruit. Phytomedicine, 16 (2-3): 17280.

Letícia Veras Costa-Lotufo, Mahmud Tareq Hassan Khan, Arjumand Ather, Diego Veras Wilke, Paula Christine Jimenez, Cláudia Pessoa, Maria Elisabete Amaral de Moraes and Manoel Odorico de Moraes. 2005. Studies of the anticancer potential of plants used in Bangladeshi folk medicine. $J$. Ethnopharmacol, 99(1):21-30

Letícia Veras Costa-Lotufo, Mahmud Tareq Hassan Khan, Arjumand Ather, Diego Veras Wilke, Paula Christine Jimenez, Cláudia Pessoa, Maria Elisabete Amaral de Moraes and Manoel Odorico de Moraes. 2005. Studies of the anticancer potential of plants used in Bangladeshi folk medicine. $J$. Ethnopharmacol., 99(1):21-30

Leverett, J., Chandra, A., Rana, J., Fast, D. J. , Missler, S. R. and Flower, D. M. 2005. Extracts of durian fruit for use in skin care compositions, US Patent Publication Number US 20070042064 A1,

Lewis, Y.S., Dwarakanath, C.T., Johar, D.S.1956. Acids and sugars in Eugenia jambolana. JSCi Ind Res., 15C: 280-281.

Li, L., Adams, L.S., Chen, S., Killian, C., Ahmed, A. and Navindra P. Seeram.2009. Eugenia jambolana Lam. berry extract inhibits growth and induces apoptosis of human breast cancer but not non-tumorigenic breast cells. J Agric Food Chem. 57:826-831.

Liang, W.J., Ma, Q.Y., Jiang, H.Z. ,Zhou, J., Pang, J. and Zhao, Y.X. 2012. A new hederagenin glycoside from Nephelium lappaceum. Chem. Nat. Compd., 47: 935-939.

Lim, T.K. 2013. Nephelium lappaceum. In: Edible Medicinal and Non-Medicinal Plants, Vol. 6: Fruits, Lim, T.K. (Ed.). Springer, Amsterdam, Netherlands, ISBN: 978-94-007-5627-4, pp: 62-71.
Lim, T. K. 2012. Edible Medicinal and NonMedicinal Plants, Vol. 1, Springer, Dordrecht, The Netherlands.

Lin, Y.F., Zhuan, Y. and Zhao, Y.H.2003. Chinese Dai Medicine Colorful Illustrations. Yunnan National Publishing House, Kunming: China. Liu, X. , Cui, C., Zhao, M., Wang „J., Luo, W., Yang, B. and Jiang, Y. 2008. Identification of phenolics in the fruit of emblica (Phyllanthus emblica L.) and their antioxidant activities. Food Chemistry, 109 (4): 909-915.

Mahendran, P. and Devi, C.S. 2001. Effect of Garcinia cambogia extract on lipids and lipoprotein composition in dexamethasone administered rats. Indian $J$ Physiol Pharmacol., 45(3):345-350.

Maheshwari, V. L., Joshi, P. V. and Patil, R. H. 2009. In vitro anti diarrhoeal activity and toxicity profile of Aegle marmelos Correa ex. Roxb. dried fruit pulp. Natural Product Radiance, 8(5): 498-502.

Mahmoud, I.I., Marzouk, M.S., Moharram, F.A., El-Gindi, M.R, Hassan. A.M..2001. Acylated flavonol glycosides from Eugenia jambolana leaves. Phytochemistry, 58:12391244.

Maity, P., Hansda, D., Bandyopadhyay, U. and Mishra, D.K. 2009. Biological activities of crude extracts and chemical constituents of bael, Aegle marmelos (L.) Corr. Indian Journal of Experimental Biology, 47(11): 849-861.

Majeed, M., Rosen, R., McCarty, M., Conte, A., Patil, D, and Butrym, E. 1994. Citrin; A revolutionary, herbal approach to weight management. New editions publishing. Burlingame, California.

Manandhar, M.D., Shoeb, A., Kapil, R.S. and Popli, S.P.1978. New alkaloids from Aegle marmelos. Phytochemistry, 17: 1814-1815.

Marwat, S. K., Khan, M. A., Ahmad, M., Zafar, M., Fazal-ur-Rehman and Sultana, S. 2009. Fruit plant species mentioned in the Holy Qura'n and Ahadith and their ethnomedicinal importance. American-Eurasian Journal of Agricultural Environmental Sciences, 5(2): 284-295. 
Marzine, P. S., and Gilbart, R. 2005.The effect of an aqueous extract of $A$. marmelos fruits on serum and tissue lipids in experimental diabetes. J. Sci. Food Agriculture, 85(4):569573.

Masullo, M., Bassarello, C, Suzuki, H., Pizza, C. and Piacente, S. 2008. Polyisoprenylated benzophenones and an unusual polyisoprenylated tetracyclic xanthone from the fruits of Garcinia cambogia. J. Agric. Food Chem., 56:5205-5210.

Masullo, M., Bassarello, C., Bifulco, G. and Piacente, S. 2010. Polyisoprenylated benzophenone derivatives from the fruits of Garcinia cambogia and their absolute configuration by quantum chemical circular dichroism calculations. Tetrahedron., 66: 139-145.

Merai, A.H. and Jadhav, A.G.2014. Anti-ulcer activity of Carissa carandas using root extract in albino rats. World J. Pharm Pharm Sci., 3: 1314-1326.

Mishra, A., Bapat, M.M., Tilak, J.C. and Devasagayam, T.P.A. 2006. Antioxidant activity of Garcinia indica (kokum) and its syrup. Curr. Sci., 91: 90-93.

Mishra, Bhuwan Bhushan, Navneet Kishore, Tiwari, Vinod K. and Tripathi, Vyasji .2009. A novel antifungal anthraquinone from seeds of Aegle marmelos Correa (family Rutaceae). Fitoterapia ,81(2):104-107

Mishra, C. K., Pattnaik, A.K., Asha Rani, Sasmal, D. and Nema, Rajesh Kumar .2009. Antifungal and antibacterial activity of Carissa carandas Linn. Int J Plant Sci., 4: 564-568.

Mishra, C.K. and Sasmal, D. 2015 In-vivo evaluation of anti-diarrhoeal activity of ethanolic fruit and root extracts of Carissa carandas. Linn. (Apocynaceae). Int. J. Drug Dev. Res.,7: 216-221.

Mishra, T., Khullar, M.and Bhatia, A. 2011. Anticancer potential of aqueous ethanol seed extract of Ziziphus mauritiana against cancer cell lines and Ehrlich ascites carcinoma, Evidence-Based Complementary and Alternative Medicine, Article ID 765029.pp11.
Miyasaka, L.S., Atallah, A.N. and Soares, B.G.O.2007. Passiflora for anxiety disorder (Review): Cochrane Database of Systematic Reviews, 24(1): CD004518.

Mohamad, S., Zin, N. M., H. A. Wahab, H.A., Pazilah, I., Sulaiman, S. F, Zahariluddin, A. S. M. and Noor, S. S. M. 2011. Antituberculosis potential of some ethnobotanically selected Malaysian plants. J. Ethnopharmacology, 133(3):1021-1026.

Mohamed, S., Hassan, Z. and Hamid, N. A. 1994. Antimicrobial activity of some tropical fruit wastes (guava, star fruit, banana, papaya, passion fruit, langsat, duku, rambutan and rambai), Pertanika Journal of Tropical Agricultural Science, 17(3): 219-227.

Mohanty,S. and Cock, I. E. 2010. Bioactivity of Syzygium jambos methanolic extracts: antibacterial activity and toxicity. Pharmacognosy Research, 2 (1):4-9.

Montanher, A.B., Zucolotto, S.M., Schenkel, E.P. and Frode, T.S. 2007. Evidence of antiinflammatory effects of Passiflora edulis in an inflammation model. Journal of Ethnopharmacology, 109: 281-288.

Morton, J. 1987. Fruits of warm climates, Florida Flair Books, Miami, Fla, USA.

Muhtadi M, Haryoto H, Tanti AzizahSujono, Andi Suhendi. 2016. Antidiabetic and antihypercholesterolemic activities of rambutan (Nephelium lappaceum L.) and durian (Duriozibet hinus Murr.) Fruit Peel Extracts. Journal of Applied Pharmaceutical Science, 6(4):190-194.

Murmu, Prabir, Kumar, Sanjeet, Patra, Jayanta Kumar, Singh, Nihar Ranjan and Rath, Sakti Kanta. 2016. Ethnobotanical, nutritional, phytochemical and antimicrobial studies of Garcinia xanthochymus fruit extracts. British Biotechnology Journal,13(2): 1-11.

Murugan, S., Devi, P. U., Parameswari, N. K. and Mani, K. R. 2011. Antimicrobial activity of Syzygium jambos against selected human pathogens. International Journal of Pharmacy and Pharmaceutical Sciences, 3(2):44-47.

NagaRaju, G.J., Sarit, P., Ramana Murty, G.A., Ravi Kumar, M., Reddy, B.S., Charles, M.J., Lakshminarayana, S., Reddy, T. S., Reddy, S.B. and Vijayan, V . 2006. Estimation of 
trace elements in some anti-diabetic medicinal plants using PIXE technique. Appl Radiat Isot., 64: 893-900.

Nair, R.A.G. and Subramanian, S.S. 1962. Chemical examination of the flowers of Eugenia jambolana., J. Sci Ind Res., 21B:457-458.

Nandkarni, A. K.1976. Indian Materia Medica. Vol.-I, (3rd ed.). Popular Prakashan, Bombay, pp.45-49.

Natarajan, B, and Paulsen, B.S. 2000. An ethnopharmacological study from Thane district Maharashtra India traditional knowledge compared with modern biological science. Pharm Biol., 38 : 139-151.

Nethaji, R, Thooyavan, G., MullaiNilla, K., Ashok, K. 2015. Phytochemical profiling, antioxidant and antimicrobial activity of methanol extract in rambutan fruit (Nephelium lappacium) epicarp against the human pathogens. Int. J. Curr. Innov. Res., 1(9): 201-206.

Nimbalkar, R. S. K. and Rajurkar, S. K. 2009. Antioxidant activities of Zizyphu smauritiana Lam. (Rhamnaceae). Biological Forum, 1(2):98-101.

Nurulhuda, M. H., Azlan, A., Ismail, A., Amom, Z. and Shakirin, F. H. 2013. Sibu olive inhibits artherosclerosis by cholesterol lowering effect in cholesterol fed-rabbit. In: Proceeding of the 4th International Conference on Biomedical Engineering, Ho Chi Minh City, Vietnam. pp. 141-144,

Nurulhuda, M. H., Azlan, A., Ismail, A., Amom, Z. and Shakirin, F. H. 2012. Cholesterollowering and atherosclerosis inhibitory effect of Sibu olive in cholesterol fed-rabbit, Asian Journal of Biochemistry, 7(2):80-89.

Ong, P.K.C., T.E. Acree and E.H. Lavin, 1998. Characterization of volatiles in rambutan fruit (Nephelium lappaceum L.). J. Agric. Food Chem., 46: 611-615.

Ovalle-Magallanes, B., Eugenio-Perez, D., Pedraza-Chaverri, J. 2017. Review: medicinal properties of mangosteen (Garcinia mangostana L.): a comprehensive update. Food. Chem Toxicol., 109:102-122.

Padhye, S., Ahmad ,A., Oswal, N. and Sarkar, F.H. 2009. Emerging role of garcinol, the antioxidant chalcone from Garcinia indica Choisy and its synthetic analogs. J. Hem. Onc., 2: 1-13.
Palakawong C., Sophanodora, P., Pisuchpen, S. and Phongpaichit, S. 2010. Antioxidant and antimicrobial activities of crude extracts from mangosteen (Garcinia mangostana L.) parts and some essential oils. Int Food Res J., 17:583-589.

Palanisamy, U.D., Ling, L.T., Manaharan, T. and Appleton, D. 2011. Rapid isolation of geraniin from Nephelium lappaceum rind waste and its anti-hyperglycemic activity. Food Chem., 127: 21-27.

Panda, S., and Kar, A. 2006. Evaluation of the antithyroid, antioxidative and antihyperglycemic activity of scopoletin from Aegle marmelos leaves in hyperthyroid rats, Phytother Res. 20(12):1103-1105.

Pandey, R., Chandra, P., Kumar, B., Srivastva, M., Aravind, A.A., Shameer, P.S. and Ramesh kumar, K.B. 2015. Simultaneous determination of multi-class bioactive constituents for quality assessment of Garcinia species using UHPLC-QqQ LITMS/MS. Ind. Crops Prod., 77:861-872.

Pandya, D.D.J. 2012. Pharmacognostic and phytochemical study of aerial parts of Carissa carandas. Int J Biol Pharm Res, 3: 75-81.

Parthasarathy, U. and Nandakishore, O.P. 2016. Garcinia bark exudates- an important phytochemical source. Curr. Sci., 110:16171619.

Parthasarathy, U., Nandakishore, O.P., Kumar, S.R., Babu, N.K, Zachariah, T.J. and Parthasarathy, V.A. 2012. Chromatographic fingerprinting and estimation of organic acids in selected Garcinia species. Int. J. Innovative Horticulture, 1:68-73.

Parvin, M.N. 2018. Phytochemical screening, antinociceptive, anthelmintic and cytotoxicity studies of the leaves of Carissa carandas Linn. (Family: Apocynaceae). Int J Sci Reports, 4: 119.

Pasha, C., Sayeed, S., Ali, M.S. and Khan, M.Z. 2009. Anti Salmonella activity of selected medicinal plants. Turkish J. Biol., 33: 59-64.

Patel, P.K., Sahu, J., Sahu, L., Prajapati, N.K, Dubey, B.K. 2012. Aegle marmelos: A Review on its Medicinal Properties. International Journal of Pharmacy and Phytopharmacology Research, 1 (5):332341. 
Patil R. H., Chaudhary B. and Settipalli, S. 2009. Antifungal and Antiaflatoxigenic activity of Aegle marmelos Linn. Pharmacognosy Journol, 1(4): 298-301.

Patil, S.P, Kalkar, S.A. and Kulkarni, A.S, 2012. Phytochemical screening, antibacterial and antioxidant activity of Limonia acidissima (L). Bionano Frontier, 5 (2-II): 131-132.

Patil, R.P., Pai, Sandeep R., Pawar, Nilesh V., Shimpale, Vinod B., Patil, Rakesh M. and Mansingraj S Nimbalkar, 2012. Chemical characterization, mineral analysis, and antioxidant potential of two underutilized berries (Carissa carandus and Eleagnus conferta) from the Western Ghats of India. Crit Rev Food Sci Nutr; 52: 312-320.

Perry, L.M.1980. Medicinal plants of East and Southeast Asia: Attributed properties and uses. The MIT Press, Cambridge, London.

Peter, K.C., Ong, Terry, Acree, E., Edward, H Lavin.1998. Characterization of volatiles in Rrambutan fruit (Nephelium lappaceumL.). J. Agric. Food Chem., 46(2):611-615.

Pitre, S. and Srivastava, S.K. 1987. Pharmacological, microbiological and phytochemical studies on the root of Aegle marmelos. Fitoterapia, 58:194-197.

Pramanik, T., Sur, T.K., Pandit, S. and Bhattacharyya, D. 2002. Effect of Aegle marmelos leaf on rat sperm motility: An in vitro study. Indian Journal of Pharmacology, 34:276-277.

Pratima, Vijavyargia and Rekha Vihavyergia. 2014. A Review on Limonia acidissima L.: Multipotential medicinal plant. Int. J. Pharm. Sci. Rev. Res., 28(1): 191-195.

Prince, P.S., Menon, V.P. and Pari, L.1998. Hypoglycemic activity of Syzigium cumini seeds: effect on lipid peroxidation in alloxan diabetic rats. $J$ Ethnopharmacol., 61(1):1-7.

Puricelli, L., Aicab, I.D., Sartorb, L., Garbisab, S. and Caniato, R. 2003. Preliminary evaluation of inhibition of matrix-metalloprotease MMP-2 and MMP-9 by Passiflora edulis and $P$ foetida aqueous extracts, Fitoterapia, 74: 302-304.
Purohit, S.S. and Vyas, S.P. 2004. In: Aegle marmelos Correa ex Roxb,(Bael), Medicinal plant cultivation- A scientific approach, Agrobios, Jodhpur, 2004. pp.498-504.

Ragasa, C.Y., de Luna, R.D., Cruz, W.C. and Rideout, J.A. 2005. Monoterpene lactones from the seeds of Nephelium lappaceum. $J$. Nat. Prod., 68: 1394-1396.

Rahman, A.M., Nahar,N., Mian and Mosihuzzaman, M. 1999. Variation of carbohydrate composition of two forms of fruit from jack tree (Artocarpus heterophyllus L) with maturity and climatic conditions. Food Chem., 65: 91-97.

Ramnik Singh and Rao, H.2008. Hepatoprotective effect of the pulp/seed of Aegle Marmelos correa ex Roxb against carbon tetrachloride induced liver damage in rats. International Journal of Green Pharmacy, 2(4): 232.

Rana, B. K., Singh, U. P. and Taneja, V. 1997. Anti-fungal activity and kinectics of inhibition by essential oil isolated from leaves of Aegle marmelos, J Ethanopharmacol., 57:29-34.

Rao, A.R., Venkataraman, K. and Yemul, S.S. 1973. The structure of bronianone. Tetrahedron Lett., 14 (50):4981-4982.

Ratnam, K. V. and Raju, R.R.V.1998. In vitro antimicrobial screening of the fruit extracts of two Syzygium species (Myrtaceae), Advances in Biological Research, 2(1-2):1720.

Ratnam, K. V. and Raju, R.R.V.2008. In vitro antimicrobial screening of the fruit extracts of two Syzygium species (Myrtaceae), Advances in Biological Research, 2(1-2):1720.

Ratsimamanga, U.1998. Native plants for our global village. TWAS Newslett. 10:13-15.

Ravi, K., Rajasekaran, S. and Subramanian, S. 2004. Antihyperlipidemic effect of Eugenia jambolana seed kernel on streptozotocinduced diabetes in rats. Food Chem Toxicol., 43(9):1433-1439.

Ravi, K., Ramachandran, B. and Subramanian, S.2004. Protective effect of Eugenia jambolana seed kernel on tissue antioxidants in streptozotocin-induced diabetic rats. Biol Pharm Bull. 27(8):1212-1227. 
Reginatto, F.H., De-Paris, F., Petry, R.D., Quevedo, J., Ortega, G.G., Gosmann, G. and Schenkel, E.P.2006. Evaluation of anxiolytic activity of spray dried powders of two South Brazilian Passiflora species. Phytother Res., 20(5): 348-351.

Remya, M.,. Sharma, R. C., Shoaib, H., Asad, U. J. R and Singh. S. 2009. In vitro effect of Aegle marmelos on human sperm motility. Journal of Medicinal Plants Research, 3(12): 1137-1139.

Reynertson, K. A. 2007. Phytochemical analysis of bioactive constituents from edible myrtaceae fruits. M.S. thesis, The City University of New York, New York, NY, USA.

Rowe-Dutton, P.1985. Artocarpus heterophyllusjackfruit. In: The propagation of tropical fruit trees (Garner RJ and Chaudhri SA, eds.). FAO, Rome (Italy); Commonwealth Bureau of Horticulture and Plantation Crops, Maidstone, 269-290.

Ruiz-Montanez, G., Burgos-Hernandez, A., Calder'on-Santoyo, M. López-Saiz, C. M., Velázquez-Contreras, C. A., NavarroOcaña,A. and Ragazzo-Sánchez, JA. 2014. Screening antimutagenic and antiproliferative properties of extracts isolated from Jackfruit pulp (Artocarpus heterophyllus Lam). Food Chemistry, 175: 409-416.

Sabu, M.C. and Khuttan, R. 2002. Anti-diabetic activity of medicinal plants and its relationship with their antioxidant property. $J$ Ethnopharmacol., 81:155-160.

Sato, M., Fujiwara. S., Tsuchiya, H., Fujii, T., Iinuma, M., Tosa, H. and Ohkawa, Y. 1996. Flavones with antibacterial activity against cariogenic bacteria. Journal of Ethnopharmacology ,54(2): 171-176.

Seigler, D.S., Pauli, G.F., Nahrstedt, A. and Leen, R.2002. Cyano-genic allosides and glucosides from Passiflora edulis and Carica papaya. Phytochemistry, 60 : 873-882.

Semwal, R.B., Semwal, D.K, Vermaak, I. and Viljoen, A. 2015. A comprehensive scientific overview of Garcinia cambogia. Fitoterapia, 102:134-148.

Sengupta, P. and Das, P. B.1965. Terpenoids and related compunds part IV triterpenoids the stem-bark of Eugenia jambolana Lam. Indian Chem Soc., 42:255258.
Senthil Kumar, A., Venkatesalu, V. , Kannathasan, K. and Chandrasekaran, M. 2010. Chemical constituents and antibacterial activity of the leaf essential oil of Feronia limonia. Indian J Microbiol., 50(1):S70-S73 .

Shankarnanth, V., Balakrishnan, N., Suresh, D., Sureshpandian, G., Edwin, E. and Sheeja E. 2007. Analgesic activity of methanol; extract of Aegle marmelos leaves. Fitoterapia, 78(3): 258-259.

Sharma, A, Tiwari, R.K., Kaushik, Atul, Tyagi, L.K. Kruna Shankar, Tarun Virmani, Suman Yadav and Nayyar Parvez. 2007. Standardisation of Carissa carandas Linn: A drug used in Indian system of medicine as per W.H.O. Guidelines. Cont J Pharm Sci.; 1: 9- 14.

Sharma, B.R., Rattan, R.K. and Sharma, P. 1980. Constituents of Aegle marmelos. Indian Journal of Chemistry, 19: 162.

Sharma, H.K., Chhangte, L. and Dolui, A.K. 2001 Traditional medicinal plants in Mizoram India. Fitoterapia, 72:146-161.

Sharma, P.C., Bhatia, V., Bansal, N. and Sharma, A. 2007. A review on bael tree. Natural Product Radiance, 6(2):171-178.

Sharma, S.B., Nasir, A., Prabhu, K.M, Murthy, P. S. and Dev. G. 2003. Hypoglycaemic and hypolipidemic effect of ethanolic extract of seeds of Eugenia jambolana in alloxaninduced diabetic rabbits. JEthnopharmacol., 85 (2-3):201-206.

Sharma, W. and Trivedi, P. C. 1995. Nematocidal and nematostostatic response of aqueous extract of certain plants of semi-arid niche. Current Nematology, 6: 45-53.

Shoeb, A., Randhir, S.K. and Popli, S.1973. Coumarins and alkaloids of Aegle marmelos. Phytochemistry, 12: 2071- 2072.

Singanan, V., Singanan, M and Begum, H. 2007. The hepatoprotective effect of bael leaves (Aegle marmelos) in alcohol induced liver injury in albino rats. International Journal of Science \& Technology,2(2) : 83-92.

Singh, Z. and Malik, A.U. 2000. The Bael. West Australian Nut and Tree Crops Association Yearbook, 24: 12-17.

Sridhar, S.B., Sheetal, U.D, Pai, M.R. and Shastri, M.S. 2005. Preclinical evaluation of the antidiabetic effect of Eugeniajambolana seed powder in streptozotocin- diabetic rats. Braz J Med Biol Res., 38(3):463-468. 
Srivastava, H.C. 1953. Paper chromatography of fruit juices. $J$ Sci Ind Res., 12B:363-365.

Subramaniya, B. R., Malliga, R. M., Malathi,G.K., Anbarasu, K. and. Devaraj, S.N. 2009. Effect of aqueous extract of Aegle marmelos fruit on Adherence and $\beta$-Lactam resistance of Enteropathogenic Escherichia coli by down regulating outer membrane protein $\mathrm{C}$. American Journal of Infectious Disease, 5 (2):161-169.

Suganthi, A. and Marry Josephine R. 2016. Nephelium Lappaceum (L.): An overview. Pharm Sci \& Res, 1(5): 36-39.

Suksamram, S., Komutiban, O., Ratananukul, P., Chimnoi, N, Lartpornmatulee, N., Suksamram A. 2006. Cytotoxic prenylated xanthones from the young fruit of Garcinia mangostana. Chem Pharm Bull., 54: 301-5.

Sumantran, V.N., Kulkarni, A., Chandwaskar, R., Harsulkar, A., Patwardhan, B., Chopra, A.and Wagh, U.V. 2008. Chondroprotective potential of fruit extracts of Phyllanthus emblica in osteoarthritis. Evid. Based Complement Alternat. Med., 5(3):329-335.

Sumbul, S. and Ahmed, S.I. 2012. Antihyperlipidemic activity of Carissa carandas (Auct.) leaves extract in egg yolk induced hyperlipidemic rats. J Basic Appl Sci., 8: 124134.

Sundaram, E., Raddy, N., Uma Maheswara, P. and Singh, K.P. 2009. Effect of alcoholic extracts of indian medicinal plants on the altered enzymatic activities of diabetic rats. Indian Journal of Pharmaceutical Sciences, 71(5):594-598.

Sur, T.K, Pandit, S. and Pramanik, T. 1999. Antispermatogenic activity of leaves of Aegle marmelos Corr. in albino rats: A preliminary report. Biomedicine, 19:199-202.

Swami, S.B, Thako, N.J. and Patil, S.C. 2014. Kokum (Garcinia indica) and its many functional components as related to the human health: A review. J. Food Res. Tech., 2:130-142.

Tajudin, T.J., Mat, S. A. , N. , Siti-Aishah, A. B., Yusran, A. A. M. , Alwi, A. and Ali, A. M. 2021. Cytotoxicity, antiproliferative effects, and apoptosis induction of methanolic extract of Cynometra cauliflora Linn. whole fruit on human promyelocytic leukemia HL-60 cells, Evidence-Based Complementary and Alternative Medicine, : ID 127373 : 6 pages.

Tamilselvi, A., Joseph, G.S. and Jayaprakasha, G.K. 2003. Inhibition of growth and aflatoxin production in Aspergillus flavus by Garcinia indica extract and its antioxidant activity. Food Microbiol., 20:455-460.

Tamimy. 2006. Antioxidant activity of ethanol extract of rambutan (Nephellium lappaceum L.) Fruit Peel against DPPH free radical suppression by spectrophotometer (In Bahasa Indonesia). Yogyakarta.

Tan, B.K.H.,.Fu, P, Chow, P.W and Hsu, A. 1996. Effects of A. Bilimbi on blood sugar and food intake in streptozotocin induced diabetic rats. Phytomedicine, 3:271-272.

Taylor, R. S. L., Manandhar, N. P., Hudson, J. B. and Towers, G. H. N. 1996. Antiviral activities of Nepalese medicinal plants. Journal of Ethnopharmacology, 52 (3): 157-163.

Taylor, R. S. L. Manandhar, N.P. and Towers, G. H. N.1995. Screening of selected medicinal plants of Nepal for antimicrobial activities. Journal of Ethnopharmacology, 46 (3):153159.

The wealth of India: 2001. A dictionary of Indian raw materials \& industrial products. Published by National Institute of Science Communication and Information Resource (NISCAIR) 14 S V Marg, New Delhi-110 067

Thitilertdecha, N., Teerawutgulrag, A., Kilburn, J.D. and Rakariyatham, N. 2010. Identification of major phenolic compounds from Nephelium lappaceum L. and their antioxidant activities. Molecules, 15:14531465.

Thomas, Asha and Ponnammal, N. R. 2005, Preliminary studies on phytochemical and antibacterial activity of Limonia acidissima L. plant parts. Ancient Science of Life, XXV (2):57-61.

Timbola, A.K., Szpoganicz, B, , Branco, A., Monache, F.D. and Pizzolatti, M.G. 2002. A new flavonoid from leaves of Eugenia jambolana. Fitoterapia, 73:174-76.

Timbola, A.K., Szpoganicz, B, Branco, A., Monache, F.D. and Pizzolatti, M.G. 2002. A new flavonoid from leaves of Eugenia jambolana. Fitoterapia, 73:174-176. 
Torres, M. P., Rachagani S., Purohit V., Pandey, Poomy, Joshi, Suhasini, Moore, Erik D., Johansson, Sonny L., Singh, Pankaj K., Ganti , Apar K. and Batra Surinder K. 2012. Graviola: a novel promising natural-derived drug that inhibits tumorigenicity and metastasis of pancreatic cancer cells in vitro and in vivo through altering cell metabolism. Cancer Letters, 323(1):29-40.

Trindade, M.B, Lopes, J.L, Soares-Costa, A., Monteiro-Moreira, A.C, Moreira, R.A., Oliva, M.L.V. and Beltramini, L.M. 2006. Structural characterization of novel chitinbinding lectins from the genus Artocarpus and their antifungal activity. Biochimica et Biophysica Acta (BBA)-Proteins and Proteomics, 1764 (1): 146-152.

Tripathi, P.C. 2018. Minor fruits for Nutritional security. In Zero Hunger India. Ed. Dr. K. V. Peter, Brillion Publishing, New Delhi pp706.

Trivedi, P. C. 2004. Ethanomedicinal plants. Pointer publisher. Jaipur: (Raj.).

Udayan, P.S., Satheesh, G., Tushar, K.V.and Balachandran, I. 2006.Medicinal plants used by the Malayali tribe of Shevaroy hills Yercaud Salem district Tamil Nadu. Zoos Print J., 21:2223-2224.

Uduwela, H., Uduwelage, Dona Harshani, Kaushalya Deraniyagala, Srianthie A. and Thiripuranathar, Gobika. 2019. Antioxidant and anti-inflammatory potential of the aqueous extract of the peel of a sri lankan variety of Nephelium lappaceum Linn. World Journal of Pharmaceutical Research, 8(2): 154-166.

Uma D Palanisamy, Lai Teng Ling, Thamilvaani, Manaharan, David Appleton. 2011. Rapid isolation of geraniin from Nephelium lappaceum rind waste using the gilson GX 281 Preparative HPLC purification system. Journal of Food Chemistry, 127:21-27.

Upadhya, S., Shanbhag, K. K., Suneetha, G., Naidu, B. M. and Upadhya, S. 2004. A study of hypoglycemic and antioxidant activity of Aegle marmelos in alloxan induced diabetic rats. Ind. J. Physiol. Pharmacol., 48:476-480.

Vaidya Gogte, V. M. 2000. Ayurvedic Pharmacology and therapeutic use of medicinal plants, . Swami Prakashananda
Ayurvedic Research center, Mumbai, pp. 656657.

Vaishnava, M.M. and Gupta, K.R.1990. Isorhamnetin 3-O-rutinoside from Syzygium cumini Lam. J. Indian Chem. Soc., 67:785786.

Vaishnava, M.M., Tripathy, A.K. and Gupta, K.R. 1992. Flavonoid glycosides from roots of Eugenia jambolana. Fitoterapia., 63:259260.

Vakharia, B., Adhvaryu, M. and Reddy, N. 2014. Evaluation of adaptogenic potential of Curcuma longa and Zizyphus mauritiana against acute noise stress induced changes in guinea pigs. The Journal of Alternative and Complementary Medicine, 20(5): A37-A37.

Varalakshmi, K.N., Sangeetha, C.G., Shabeena, A.N., Sunitha, S.R. and Vapika, J. 2010. Antimicrobial and cytotoxic effects of Garcinia indica fruit rind extract. Am. Euras. J. Agric. Environ. Sci., 7: 652-656.

Veerappan, A., Miyazaki, S., Kadarkaraisamy, M., Ranganathan, D. 2007.Acute and subacute toxicity studies of Aegle marmelos Corr., an Indian medicinal plant. Phytomedicine, 14 (23):.209-215.

Venkataraman, K. 1973. Pigments of Garcinia species. Indian National Science Academy, New Delhi. 39(A) 6: 365-381.

Venkateswarlu, G.1952. On the nature of the colouring matter of the jambul fruit (Eugenia jambolana). J. Indian Chem Soc., 29: 434437.

Vikrant, V., Grover, J.K., Tandon, N., Rathi, S. S., Gupta, N. 2001.Treatment with extracts of Momordica charantia and Eugenia jambolana prevents hyperglycemia and hyperinsulinemia in fructose fed rats. $J$ Ethnopharmacol. 76:139-143.

Wahab, N. H. A.,Wahid, M.E.A.,Taib, M.,Zain,W.Z.W.M. and Anwar, S. A. 2009. Phytochemical screening and antimicrobial efficacy of extracts from Averrhoa bilimbi (Oxalidaceace) fruits against human pathogenic bacteria. Pharmacognosy Journal, 1(1):64-66.

Wang M-H, Zhang, K-J, Gu, Q-L, Bi, X-Land Wang, J-X. 2017. Pharmacology of mangostins and their derivatives: A 
comprehensive review. Chin. J. Nat. Med., 5:81-93.

Wetprasit, N., Threesangsri, W., Klamklai, N. and Chulavantol, M. 2000. Jackfruit lectin: properties of mitogenicity and the inhibition of herpes virus infection. Jpn. J. Infect. Dis., 53:156-161.

Whitmore, M.A. 1973. Tree Flora of Malaya, Malaysia: Forest Department, Ministry of Primary Industries, Longman, Malaysia, 206.

Yang, L.-L., Lee, C.-Y. and Yen, K.-Y. 2000. Induction of apoptosis by hydrolyzable tannins from Eugenia jambos L. on human leukemia cells. Cancer Letters, 157(1):65-75.
Zadernowski, R., Czaplicki, S. and Naczk, M. 2009. Phenolic acid profiles of mangosteen fruits (Garcinia mangostana). Food Chemistry, 112: 685-689.

Zeng, L., Wu, F. E., Gu, Z. M. and McLaughlin, J. L.1995. Murihexocins A and B, two novel mono-THF acetogenins with six hydroxyls from Annona muricata (Annonaceae) Tetrahedron Letters, 36(3):5291-5294.

Zhong, F.F., Chen, Y., Yang, G.Z.2008. Chemical constituents from the bark of Garcinia xanthochymus and their 1,1 -diphenyl -2picrylhydrazyl (DPPH) radical -scavenging activities. Helv Chim Acta., 91:1695-1703. 